\title{
Redox conditions in the Late Cretaceous Chalk Sea: the possible use of cerium anomalies as palaeoredox indicators in the Cenomanian and Turonian Chalk of England
}

\author{
CHRISTOPHER V. JEANS ${ }^{1}$, DAVID S. WRAY ${ }^{2}$ and C. TERRY WILLIAMS ${ }^{3}$ \\ ${ }^{1}$ Department of Geography, University of Cambridge, Downing Place, Cambridge CB2 3EN, U.K. \\ E-mail:cj302@cam.ac.uk \\ ${ }^{2}$ Department of Earth and Environment Sciences, University of Greenwich, Pembroke, Chatham Maritime, \\ Kent ME4 4TB, U.K. \\ ${ }^{3}$ Department of Mineralogy, Natural History Museum, Cromwell Road, London SW7 5BD, U.K.
}

\begin{abstract}
:
Jeans, C.V., Wray, D.S. and Williams, C.T. 2015. Redox conditions in the Late Cretaceous Chalk Sea: the possible use of cerium anomalies as palaeoredox indicators in the Cenomanian and Turonian Chalk of England Acta Geologica Polonica, 65 (3), 345-366. Warszawa.

The cerium anomalies preserved in the Chalk have been investigated as possible palaeoredox indicators of the Late Cretaceous Sea and its sediment. This has been based upon over a hundred new rare earth element analyses of selected samples and grain size fractions from the Chalk. Particular attention has been given to the methodology of differentiating between the cerium anomalies preserved in the bioclastic calcite and those in carbonate-fluorapatite preserved in the acetic acid insoluble residues of chalks. Variations in the cerium anomaly of different particle size fractions of uncemented chalks suggest that fractionation of rare earth elements between the Chalk's seawater and the various organisms that contributed skeletal material to the bioclastic calcite of the Chalk may have occurred. Post-depositional processes of calcite cementation and late diagenetic sulphidisation have had no apparent effect on the cerium anomaly of the acetic acid insoluble residues. The cerium anomalies associated with the acetic acid insoluble residues from (1) an alternating sequence of chalks and marls from Ballard Cliff (Dorset, UK) typical of Milankovitch cyclicity show a marked diagenetic pattern, whereas those from (2) non-volcanic and volcanic marls display a pattern that is best explained by the variations in the availability of phosphorus and the timing of argillisation of volcanic glass during diagenesis. The general conclusion is drawn that the cerium anomalies preserved in the Chalk can provide an insight into the changing palaeoredox conditions in the Late Cretaceous Sea as well as in the pore fluids of its sediments.
\end{abstract}

Key words: Chalk environments; Rare earth element (REE) anomalies; Methods; Palaeoredox indicators; Diagenesis; History.

\section{INTRODUCTION}

The changing redox conditions - that is the availability of oxygen - within the Late Cretaceous Chalk
Sea and its sediments must have played an important role in influencing the nature of the European Chalk as it is preserved today after $60-100$ million years of diagenesis. Not only did the changing redox conditions 
influence the faunas and floras that lived within the water column and on the seafloor but they also affected post-depositional processes - the preservation of organic matter, the varieties of calcite cement, and, the types of authigenic clay and iron minerals. Of particular interest has been the problem of the changes in the fossil faunas and floras that were widespread at certain times in the Chalk Sea, such as those associated with the Cenomanian-Turonian Anoxic Event. Do they reflect changes in the physical and chemical conditions of the sea or were they the result of invasions, unrelated to such changes, by more successful populations of new species? Comparison with the habitat of similar modern species may suggest an answer. An idea of the temperature and salinity can be gained from the stable oxygen isotope ratios of fossil groups (belemnites, brachiopods, bivalves, foraminifera, coccoliths) preserved in the Chalk (e.g. Jeans et al. 1991; Voigt et al. 2003) and possibly by the use of other proxies that are applied to foraminifera in the study of the recent history of oceans $(\mathrm{Mg} / \mathrm{Ca}$ ratios - Sadekov et al. 2014, Hönisch et al 2013; Sr/Ca ratios - Mortyn et al. 2005; U/Ca ratios - Yu et al. 2008; B/Ca ratios - Yu et al. 2007) as long as post-depositional change has not modified or destroyed the record. Some indication of the chemistry of the environment in the Chalk Sea can be gained from the varying trace element composition in the calcite skeletons of fossil organisms (e.g. Jeans et al. 1991) as well as from studies (e.g. Blumenberg and Wiese 2012)

\section{Cariaco Trench}

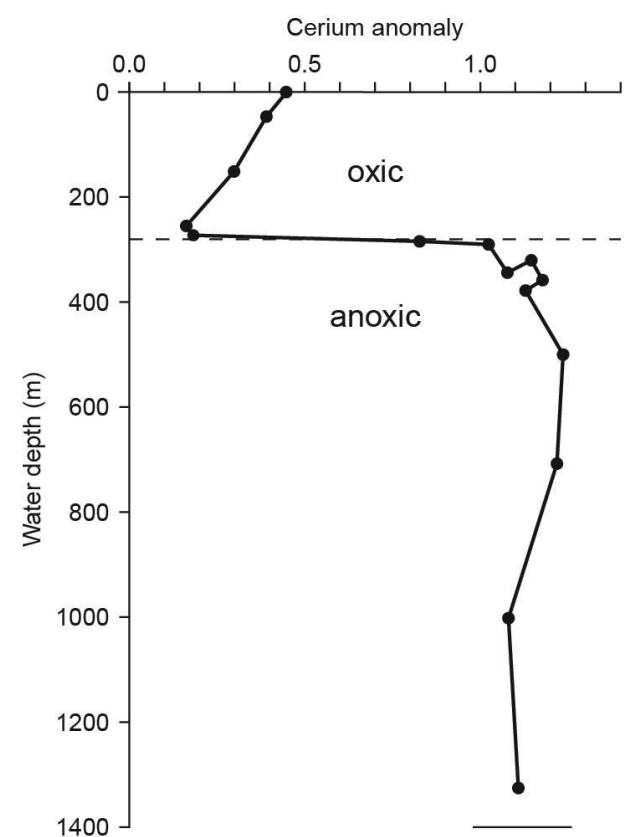

of the organic geochemistry and biomarkers within the organic fraction. A method of particular promise that has not been applied in reconstructing the palaeoredox conditions in the Chalk is that proposed by German and Elderfield (1990); this is based on studies of the pattern of rare earth elements in the present oceans. These authors suggested that the patterns of rare earth elements preserved within (a) the skeletal material of organisms living within the present oceans and (b) authigenic minerals formed within the sediments can be used as a palaeoredox record with some degree of confidence as long as four ground rules are satisfied.

This method is based upon the exceptional chemical properties of the rare earth element cerium $(\mathrm{Ce})$ in that (1) it can readily undergo oxidation from the solvated $3^{+}$state to the insoluble Ce (IV), and (2) the fractionation of cerium relative to the other strictly trivalent rare earth elements can only be affected by redox processes. The normalisation of the measured cerium abundances to those of the rare earth element series allow the extent of the oxidative removal of cerium from solution to be deduced - this is referred to as the cerium anomaly $\left(\mathrm{Ce}^{*}\right)$. Studies of the present oceans demonstrate that the cerium anomaly is a sensitive measure of the redox conditions.

The four ground rules of German and Elderfield (1990) are listed below. They underlie the use of the cerium anomaly as a palaeoredox proxy and are therefore of relevance to the study of the Chalk Sea.

\section{Saanich Inlet}

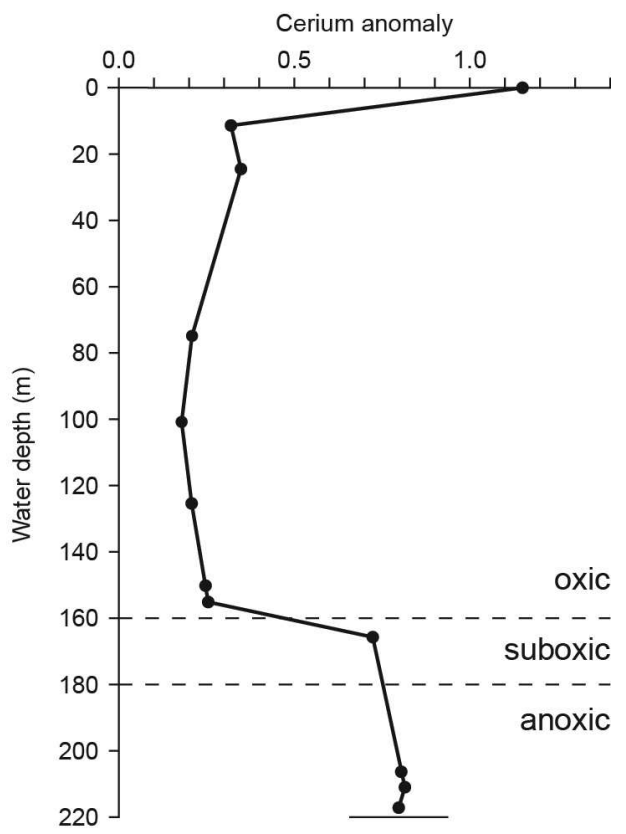

Text-fig. 1. The relationship between the cerium anomalies, redox conditions and depth in the ocean waters at Saanich Inlet (after German and Elderfield 1989) and the Cariaco Trench (after de Baar et al. 1988) 
1. The oxidation state of cerium in seawater should respond in a predictable manner to redox conditions in the water column. Studies in present oceans (e.g. Cariaco Trench, de Baar et al. 1988; Saanich Inlet, German and Elderfield 1989; N.W. Indian Ocean, German and Elderfield 1990) show that all rare earth elements are enriched under suboxic and anoxic conditions but cerium is preferentially enriched (Text-fig. 1).

2. The negative/positive cerium anomaly measured in seawater should represent an instantaneous record of the oxic/anoxic conditions in the water column at the time the rare earth elements are incorporated into the relevant solid phase. German and Elderfield (1990) conclude that cerium appears to undergo progressive oxidative removal from the deep oceans during the ageing of individual water masses. Thus the cerium anomaly in any seawater sample may only represent an integrated record of the redox history of that particular water mass.

3. The cerium anomaly recorded by the solid phase should be related to that of the seawater source in a predictable manner. German and Elderfield (1990) observe there is some evidence that fractionation of rare earth elements takes place between seawater and the rare earth elements incorporated into the calcite shells of foraminifera. The extent to which this has occurred between the Chalk's seawater and the calcite skeletons of organisms that inhabited it, is an important aspect in assessing the significance of the cerium anomaly in the Chalk.

4. The cerium anomaly recorded by the solid phase should undergo no alteration during diagenesis. This is of particular importance for the Upper Cretaceous Chalk as it has undergone 60 to 100 million years of diagenesis.

The paper reviews the history and significance of previous research into the rare earth element contents of the Upper Cretaceous Chalk. It describes 120 new rare earth element analyses of the calcite and acetic acid insoluble fractions from chalk samples of Albian, Cenomanian and Turonian age, and then discusses their significance in regard to the extent that their cerium anomalies can be used as palaeoredox proxies of the Chalk Sea and the pore waters of its sediments. A future paper ((Jeans et al. in prep.) will describe the application of the cerium anomaly as a paleoredox indicator to the Cenomanian-Turonian Anoxic Event.

\section{PREVIOUS RESEARCH}

Jarvis (1984) was first to investigate the rare earth elements in the Chalk of England. He demonstrated in a series of white chalks and phosphatic chalks of Santonian-Campanian age that the rare earth elements of the total sample were correlated positively with the $\mathrm{P}_{2} \mathrm{O}_{5}$ content and were hosted by authigenic carbonate-fluorapatite, the typical apatite of the Chalk, which Jarvis (1980) had separated using 0.5 molar acetic acid buffered at pH5. Jarvis (1984) noted that the shale-normalised rare earth element patterns had pronounced negative cerium anomalies, which were generally similar to the patterns from recent ocean bottom oxic waters; a minor depletion in heavy rare earth elements relative to intermediate ones could reflect an original feature of the Late Cretaceous water mass from which they were derived. The next step in understanding the distribution of the Chalk's rare earth elements were unpublished analyses carried out by CTW at the Natural History Museum (London) in 1987 of total samples and acetic acid insoluble residues from the Lower, Middle and Upper Chalk of England. This demonstrated that the concentration of rare earth elements in the calcite and acid insoluble residues were different. Concentrations in the acid insoluble residues (10-100 ppm) were approximately an order of magnitude greater than in the calcite $(1-10 \mathrm{ppm})$. The general patterns in the two fractions were similar although in detail there were significant differences - of particular interest were variations related to the cerium anomalies. These observations of Jarvis $(1980,1984)$ and CTW (unpublished) indicate that the rare earth element patterns of the Chalk Sea and its sediment are still preserved in two locations: (1) in the Chalk's authigenic carbonate-fluorapatite that is essentially unaffected by weak acetic acid dissolution and is preserved in the acid insoluble residue, and (2) in the phosphorus-containing calcite that is readily dissolved. Indirect support for this partition of rare earth elements comes from Perrin's (1964) demonstration by the dissolution of a Middle Chalk sample in 2 molar acetic acid buffered at $\mathrm{pH} 3$ that a low concentration of phosphorus (147 ppm) resided in the calcite whereas the acid insoluble residue had a much higher concentration (2140 ppm). A possible complication was Perrin's suggestion that some of the phosphorus in the acid insoluble residue resulted from the partial reprecipitation of dissolved phosphate during the experiment; Weir and Catt (1965) found no evidence of this reprecipitation in their separation and study of the clay minerals and their associated apatite from the Upper Chalk of Sussex, however our own experiment (see later) using $2 \%$ $\mathrm{HNO}_{3}$ indicates that reprecipitation of phosphorus may occur. 


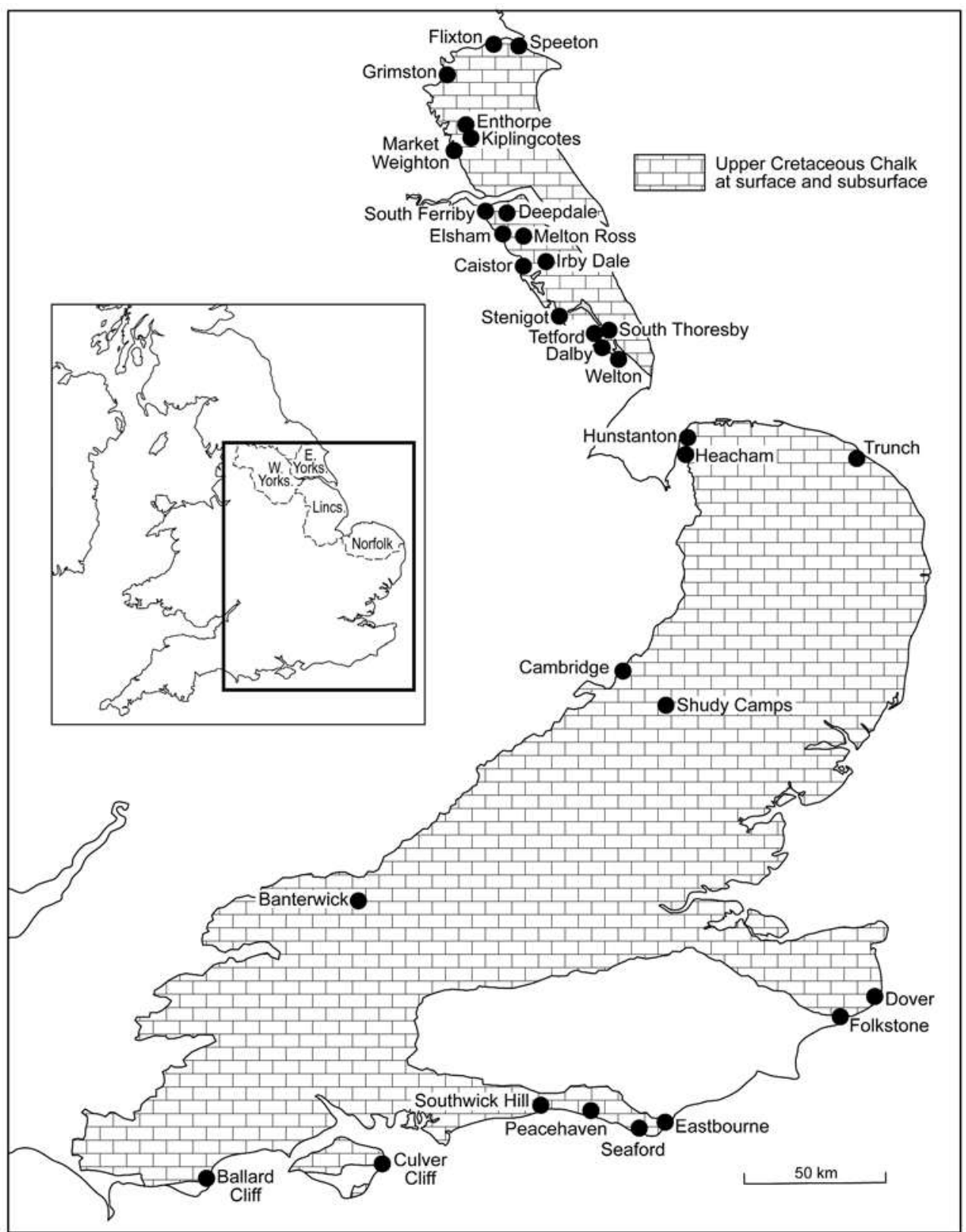

Text-fig. 2. Outcrop and subcrop distribution of the Upper Cretaceous Chalk in England. Locations mentioned in the text are shown as well as those referred to in related papers (Hu et al. 2012, 2014; Jeans et al. 2012, 2014)

\section{NEW INVESTIGATION}

Our study has been based upon the finding that two cerium anomalies are preserved in the Chalk (see above); one linked to the original calcite skeletons of organisms that lived in the Chalk Sea, the other to carbonate-fluorapatite which reflects conditions in the porewaters of its sediment. The questions we have attempted to answer are as follows: (1) How to differentiate between the anomalies in the original bioclas- tic calcite and those developed during diagenesis? (2) To what extent has there been fractionation of the rare earth elements between the Chalk Sea and the calcitic skeletons of the organisms that lived in it? (3) Has the cerium anomaly of the pore waters been modified by the addition of volcanic ash as measured by the europium anomaly? And (4) Have the original cerium anomalies in the bioclastic calcite and in the carbonate-fluorapatite in the acetic acid insoluble residues been modified by subsequent diagenesis? 


\section{Eastern England}

\section{Dover, Kent}

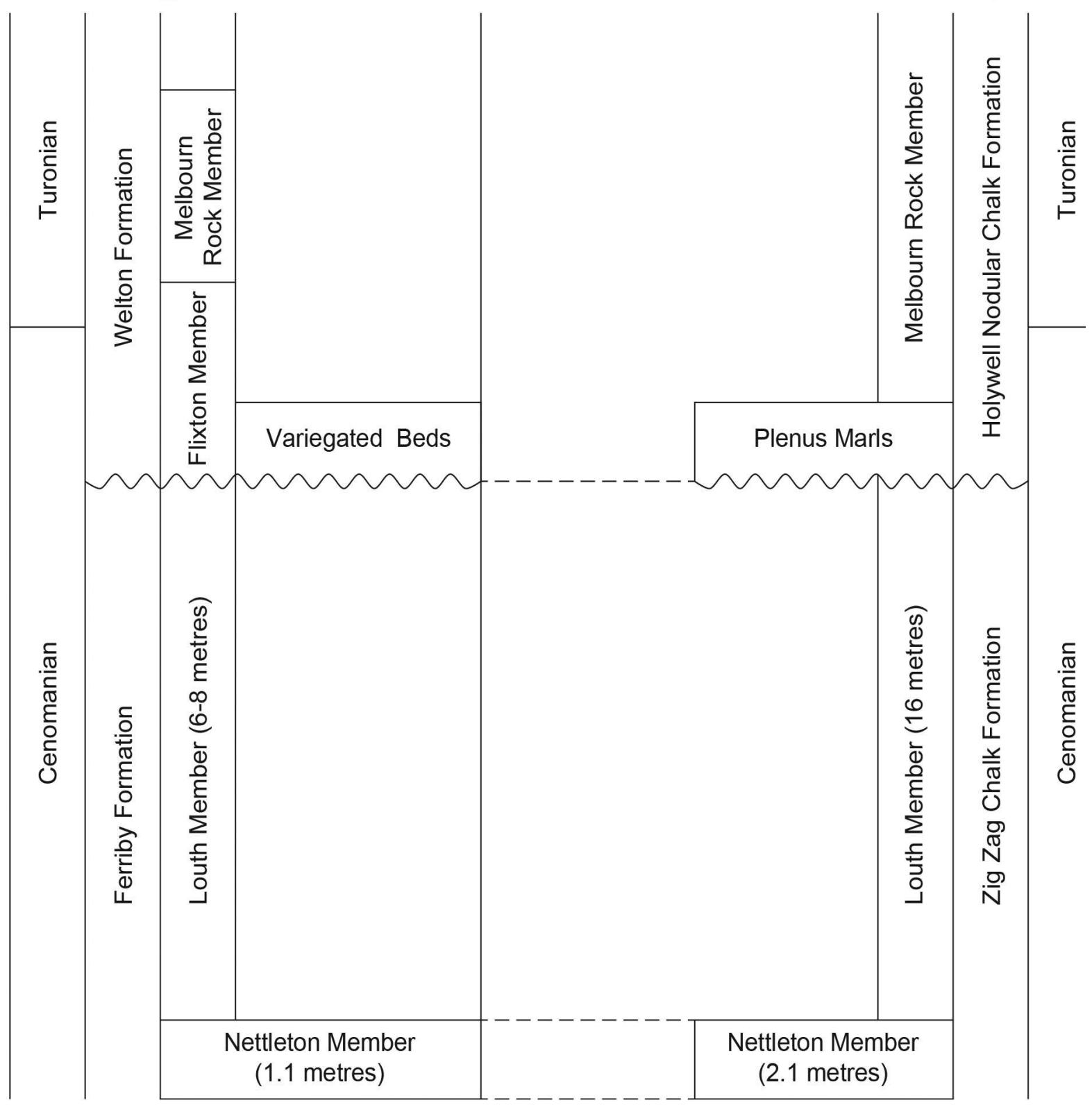

Text-fig. 3. Lithostratigraphical and stratigraphical terms used in eastern and southern England

Text-fig. 2 shows the regional extent of the Upper Cretaceous Chalk in England and the various locations mentioned in the text. Text-fig. 3 shows the stratigraphical terms used.

\section{ANALYTICAL METHOD}

120 samples of Chalk have been investigated. The great majority are of Cenomanian age, a small number are of Turonian or Late Albian age. Details of their lo- cations and stratigraphical levels are given in fig. 10 of Jeans et al. (1991) for Flixton, in text-fig. 4 of $\mathrm{Hu}$ et al. (2012) for Speeton, in text-fig. 5 of Jeans et al. (2014) for Elsham, Tetford, South Thoresby and Welton, and in Text-fig. 6 of this paper for Dover and Folkestone.

The new rare earth element analyses (Tables 1-6) are based in part on two methods. The acid insoluble residues (AIR) were extracted by dissolving the calcite fractions of crushed chalk samples in cold 1 molar acetic acid, whereas calcite for analysis was prepared 
by dissolving crushed chalk samples (or separated particle size fractions) in $2 \%$ nitric acid. Rare earth element analysis was carried out in two phases: prior to 1995 the acid insoluble residues of samples were analysed by CTW using the instrumental neutron activation method (Henderson and Williams 1981); from 1995 onwards the calcite fractions and the acid insoluble residues were analysed by DSW using Inductively Coupled Plasma-Mass Spectroscopy (ICP-MS). The limit of determination for all rare earth elements was found to be less than $0.1 \mathrm{mg} / \mathrm{kg}$. A determination of expanded uncertainty ( $\mathrm{K}=2,95 \%$ confidence) derived from eleven measurements of duplicate preparations of a number of reference materials over 5.5 days established uncertainty values of $\pm 10-12 \%$ for the rare earth elements.

The calculation of the cerium and europium anomalies of a particular rare earth element analysis has in this account been based on the following procedures:

$$
\text { Ce anomaly }=\frac{\mathrm{Ce} \mathrm{s} / \mathrm{n}}{(0.8 \times \mathrm{La} \mathrm{s} / \mathrm{n})+(0.2 \times \mathrm{Sm} \mathrm{s} / \mathrm{n})}
$$

Ce $\mathbf{s} / \mathbf{n}, \mathbf{L a} \mathbf{s} / \mathbf{n}$ and $\mathbf{S m} \mathbf{s} / \mathbf{n}$ refers respectively to the shale-normalised values of cerium (Ce), lanthanum (La) and samarium (Sm) for the particular sample relative to the Cody Shale (SCo-1) standard. Cerium anomaly $\left(\mathbf{C e}^{*}\right)$ values of $>1.0, \sim 1.0$ and $<1.0$ are referred to, respectively, as positive, neutral (no anomaly) and negative. Ce*(calcite) and $\mathbf{C e}$ (AIR) refers to the cerium anomalies associated, respectively, with the calcite fractions and acid insoluble residues of the Chalk.

$$
\text { Eu anomaly }=\frac{\mathrm{Eu} \mathrm{s} / \mathrm{n}}{(5.40 \times \mathrm{Sm} \mathrm{s} / \mathrm{n})+(4.43 \times \mathrm{Gd} \mathrm{s} / \mathrm{n})}
$$

$\mathbf{E u ~ s / n , ~ S m ~ s / n ~ a n d ~} \mathbf{G d} \mathbf{s} / \mathbf{n}$ refers respectively to the shale-normalised values of europium (Eu), samarium (Sm) and gandolinium (Gd) for the particular sample relative to the Cody Shale (SCo-1) standard. Eu*(calcite) and $\mathbf{E u}$ *(AIR) refers to the europium anomalies associated, respectively, with the calcite fractions and acid insoluble residues of the Chalk.

\section{DIFFERENTIATION BETWEEN CERIUM ANOMALIES}

The necessity for ICP-MS analysis of using a weak mineral acid ( $2 \%$ nitric acid) instead of cold 1 molar acetic acid to extract the calcite-associated rare earth elements from our samples could result not only in the dissolution of the calcite but also in the partial dissolution of the carbonate-fluorapatite in which the cerium anomaly of the Chalk pore waters is preserved. In the most extreme case, all the carbonate-fluorapatite might be dissolved by the $2 \%$ nitric acid. The resulting rare earth element pattern would be dominated by, and probably indistinguishable from, that preserved in the carbonate-fluorapatite as the concentration of rare earth elements is an order of magnitude higher than in calcite. Such is not the case because the systematic study of the patterns extracted by these methods from chalks at three locations associated with CenomanianTuronian Anoxic Event (Jeans et al. in prep.) show that there are two distinct patterns, albeit similar, which may vary independently of each other.

We have also investigated experimentally the effect of using $2 \%$ nitric acid by comparing the different values for the cerium anomaly of the calcite obtained from using 0.5 molar acetic acid buffered at $\mathrm{pH} 5$ with those obtained by the weak mineral acid. In both instances analysis were carried out by ICP-MS. Eighteen samples were tested, seven from the Plenus Marls at Dover, eleven from the Variegated Beds succession at Flixton. All but one sample displayed an increase in values of the cerium anomaly for the calcite with the $2 \%$ nitric acid extract. For the Dover samples (Textfig. 6) the acetic acid extract values are as follows, the nitric acid extract values are shown in parentheses: E19, 0.33(0.35); E20, 0.32(0.35); E21, 0.35(0.41); E22, 0.35(0.40); E23, 0.37(0.39); E24, 0.34(0.37); E25, 0.36(0.41). The Flixton samples (Jeans et al., in prep.) were chosen to represent conspicuous low value spikes of $\mathrm{Ce}^{*}$ (calcite) that are clearly differentiated from the $\mathrm{Ce}^{*}$ (calcite) values of the underlying and overlying samples. One sample (LR322) showed a decrease in value $(0.25 \mathrm{cf}$. 0.27$)$ whereas the remaining samples displayed varying increases. However, the value of only one sample (Ysa85) was sufficiently increased to bring it into line with the trend displayed by the underlying and overlying samples. The effects of contact time between $2 \%$ nitric acid and a marl sample (Ysa83) from Flixton on the cerium anomaly of the calcite was also investigated. The sample was dissolved in excess cold $2 \%$ nitric acid over a period of 17 hours with solution samples being extracted first at 5 minutes after the initial contact between acid and sample, then at 10 minute and 20 minute intervals up to 120 minutes, and then at $180,240,360$ and 1020 minutes. The solutions were analysed for their rare earth elements as well as their phosphorus content (this reflects both phosphorus in the calcite and possibly also in the carbonate-fluorapatite of the acid insoluble residue in which relatively high concentrations of the rare earth elements are hosted; see later). Text-fig. 4 shows the changes with time of the con- 
centration of cerium and phosphorus in solution and the corresponding values of the calcite's cerium anomaly. Over the first 2 hour period the average cerium anomaly was 0.81 compared to 0.80 after the first five minutes. In the solution there was no appreciable increase in phosphorus after the first 5 minutes; in contrast, cerium increased from $760 \mu \mathrm{g} / \mathrm{L}$ (5 minutes) to $1100 \mu \mathrm{g} / \mathrm{L}$ (17 hours). A likely explanation is that phosphorus was precipitating out of solution during the experiment (cf. Perrin 1964) and the concentration of $40 \mathrm{mg} / \mathrm{L}$ represents the limit for this element under these conditions. As a result of this experiment contact time between sample and $2 \%$ nitric acid was limited to 2 hours for the determination of the rare earth elements from the calcite fraction.

Our experiments demonstrate that the use of $2 \%$ nitric acid instead of a weak acetic acid digest does make a slight difference by generally increasing the calcite's cerium anomaly; however, if the time of contact between acid and sample is kept to approximately
2 hours, there is little change in the pattern of variation, only a displacement to slightly higher values. The conclusion can be drawn that within these limitations the two types of cerium anomalies have been measured, one associated with the calcite fraction, the other with the acid insoluble residue.

\section{RARE EARTH ELEMENT PATTERNS IN THE CHALK}

A range of typical shale-normalised examples of patterns from the Chalk is illustrated in Text-fig. 5. The great majority of the rare earth element analyses of both the calcite and the acid insoluble residue have shale-normalised patterns with a pronounced negative cerium anomaly, however their shapes are generally different. Calcite patterns display usually a flat form but with enhanced lanthanum values and a gradual increase in the intermediate and heavy groups relative to the light group (Text-fig. 5f).

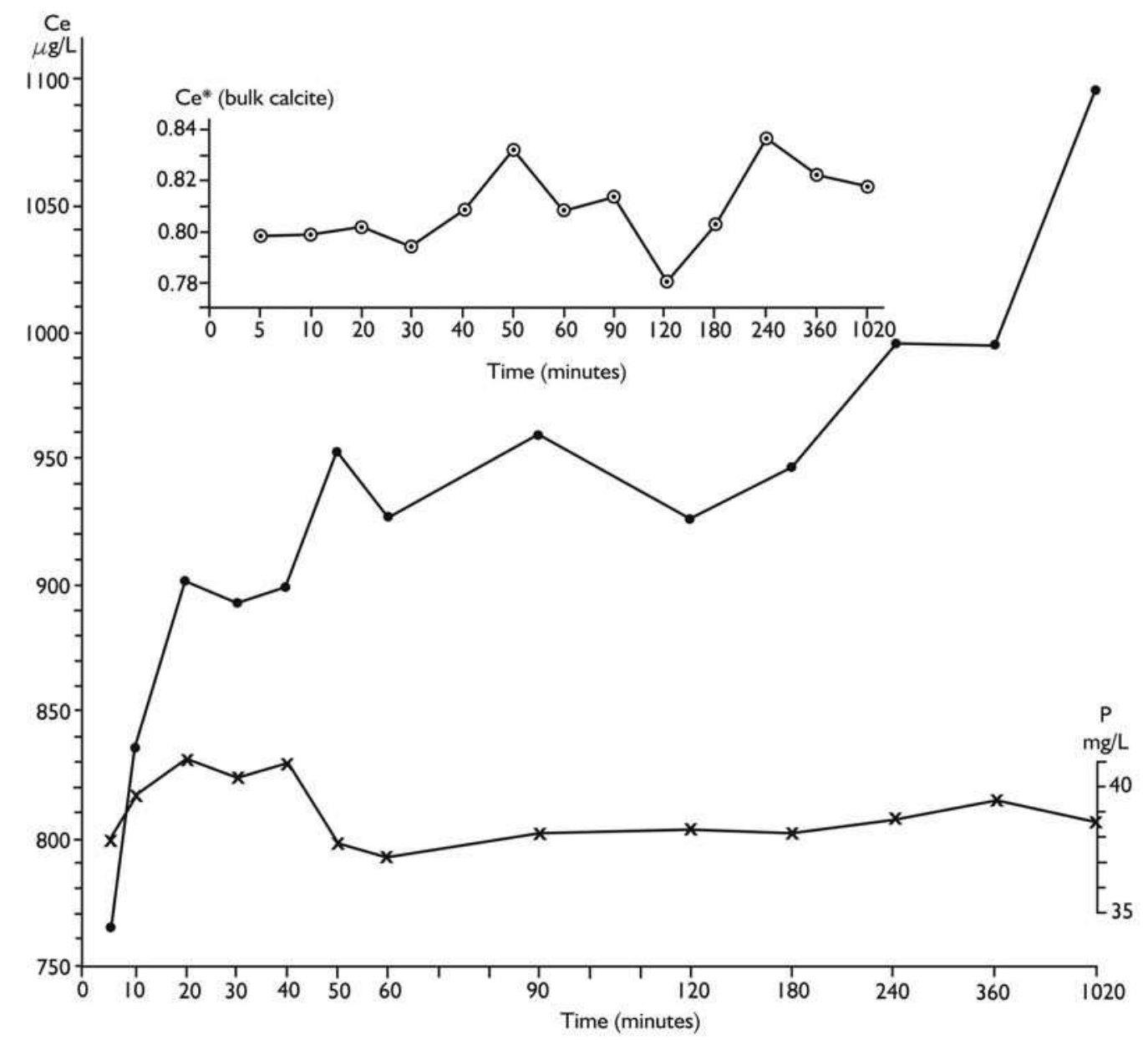

Text-fig. 4. Cross-plots showing the variations with time in the concentration of cerium $(\mathrm{Ce} \mu \mathrm{g} / \mathrm{L}$ ), the cerium anomaly (Ce* (bulk calcite)) and the phosphorus concentration (P. mg/L) in the solution during the experimental dissolution of the calcite fraction of sample Ysa 83 (Flixton Member, Flixton) in excess cold $2 \%$ nitric acid 


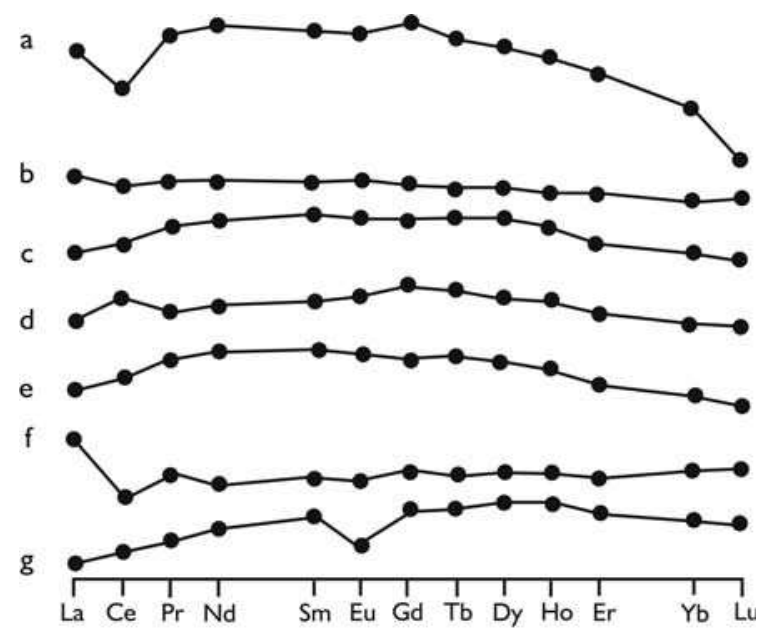

Text-fig. 5. Rare earth element patterns, normalised to the Cody Shale (SCo-1) standard, of the acetic acid insoluble residues (AIR) and calcite fraction of chalks and marls from Cenomanian and Turonian strata. a - Typical, generally convex form with a pronounced negative cerium anomaly (0.60). Sample LR317 (AIR), Melbourn Rock Member, Flixton (Jeans et al.1991. fig. 10). b Flat, less convex form with a negative cerium anomaly (0.88). Sample DoSa4 (AIR), alternating chalk-marl facies, Zig Zag Formation, Ballard Cliff(Text-fig. 13). $\mathbf{c}$ - Typical convex form with no pronounced cerium anomaly (0.88). Sample LR305 (AIR), Flixton Member, Flixton (Jeans et al. 1991, fig. 10). d - Typical convex form with a pronounced positive cerium anomaly (1.32). Sample Ysa86 (AIR), Flixton Member, Flixton (Jeans et al. 1991 fig.10). e - Typical convex form with no pronounced cerium anomaly (0.99). Sample LR303 (AIR), Flixton Member, Flixton (Jeans et al. 1991, Fig. 10). f - Typical flat form with a slight gradual increase of heavier REE and a pronounced negative cerium anomaly (0.45). Sample LR303 (calcite), Flixton Member, Flixton (Jeans et al. 1991, fig. 10). $\mathbf{g}$-Convex form with a slight negative cerium anomaly (0.96) and a pronounced europium anomaly (0.63). Sample J66 (AIR), Deepdale Lower Marl, Welton Formation (Wray and Wood 1998, fig. 3)

Patterns from acid insoluble residues are usually convex in form, displaying a variable, gradual depletion in heavy rare earth elements (Text-fig. 5a). The analyses from the chalk-marl facies of Ballard Cliff (Text-fig. 5b) have a nearly flat pattern, still with a negative cerium anomaly and an inclination to a slight gradual depletion in heavy rare earth elements.

The only exceptional patterns are from strata associated with the Cenomanian-Turonian $\mathrm{d}^{13} \mathrm{C}$ excursion at Melton Ross and Flixton, where the cerium anomaly ranges from strongly negative to strongly positive (Text-figs 5a, c, d, e). The exceptional negative cerium anomalies (Text-fig. 5f) are linked to enhanced values of lanthanum. In the majority of samples the value of the cerium anomaly for calcite is less than that for the acid insoluble residue; however, at Melton Ross values may be similar or reversed (Jeans et al.in prep.). Compared to published data on the shale-normalised patterns of the rare earth elements from total samples of Santonian-Campanian (Jarvis 1984) and Cenomanian-Turonian strata (Wood et al.
1997; Wray and Wood 1988) there is little difference: none of the new analyses displays negative europium anomalies associated with a depletion in light rare earth elements and a slight negative cerium anomaly such as reported by Wray and Wood (1988) from certain marls in eastern England and linked by them to a volcanogenic origin (Text-fig. $5 \mathrm{~g}$ ).

Differences in the concentration of rare earth elements in the calcite and acid insoluble residue (AIR) are usually marked. The La (AIR)/La (calcite) values range from 1.1 to 43 and the averages for different Chalk units range from 3.1 to 43 (Table 1). The Plenus Marls at Dover and the Variegated Beds sequences at Melton Ross and Flixton, both rich in acid-insoluble residue (up to $80-90 \%$ ), display less marked differences in the concentration of rare earth elements between the acid insoluble residues and calcite fractions than the underlying Louth Member and the overlying Melbourn Rock Member, both of which have a low content of acid insoluble residue (up to 10\%). There is, however, no obvious correlation between the weight percent of acid insoluble residue and the La (AIR)/La (calcite) values; the regional variations can be related to the dilution effects of the late diagenetic calcite cementation in eastern England that affected the sections at Melton Ross and Flixton, causing La (AIR)/La (calcite) values often to exceed 15 .

At Dover, in the Cenomanian and Lower Turonian Chalk succession the relationship between the total content of acid insoluble residue, its cerium anomaly and its content of phosphorus $\left(\right.$ as $\left.\mathrm{P}_{2} \mathrm{O}_{5}\right)$ and $\mathrm{TiO}_{2}$ has been examined (Text-fig. 6); the rare earth element analyses are in Table $2 . \mathrm{TiO}_{2}$ is used as a proxy for the continental silicate detritus in the acid insoluble residue. Text-fig. $6 \mathrm{~b}$ show that over this stratigraphical interval there is no general correlation. The stratigraphical patterns displayed by the cerium anomaly and the phosphorus are independent of each other (Text-fig. 6a). The conclusion to be drawn is that the cerium anomaly is effectively independent of the continental silicate contribution to the Chalk Sea during Cenomanian and Early Turonian times. Later in this paper it will be shown that when the main part of the acid insoluble residue is volcanic ash this may have a marked influence on its cerium anomaly.

\section{FRACTIONATION OF RARE EARTH ELEMENTS BETWEEN THE CHALK SEAWATER AND BIO- GENIC CALCITE}

The soft uncemented or only very slightly cemented Chalk at Dover can be disaggregated into its 
REDOX CONDITIONS IN THE LATE CRETACEOUS CHALK SEA

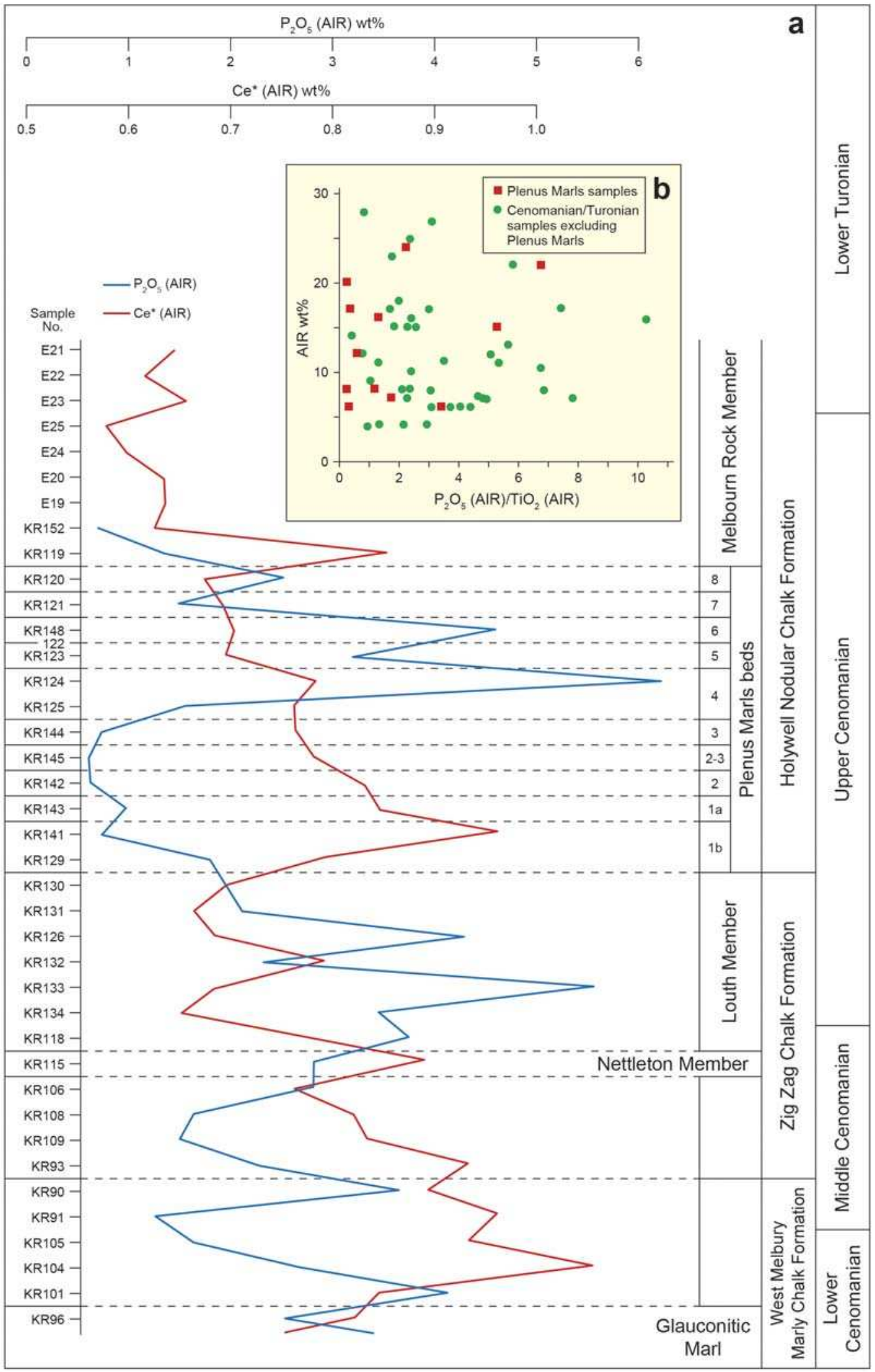

Text-fig. 6. a - This shows (1) The schematic arrangement of samples in the Cenomanian (including the Plenus Marls) and Turonian Chalk at Dover/Folkestone; and (2) the variations in the acid insoluble residue and its $\mathrm{P}_{2} \mathrm{O}_{5}$ content (reflecting carbonate-fluorapatite) and its cerium anomaly (Ce*(AIR)). b - Cross-plot of the acid insoluble residue (AIR) and its $\mathrm{P}_{2} \mathrm{O}_{5}$ (AIR)/TiO 2 (AIR) ratio for the Cenomanian and Turonian Chalk from Dover/Folkestone shown in Text-fig. 6a 
component grains. Text-fig. 7 shows the variation in the cerium anomaly of the fossil skeletal calcite for different particle size fractions in two samples from Dover (Table 2) - KR145 from Jefferies Bed 2-3 of the Plenus Marls, and KR119 from the base of the Melbourn Rock Member. Both samples show high values in the $<2 \mu \mathrm{m}$ fraction (probably coccolith debris-dominated) decreasing in the silt fractions $(2-8 \mu \mathrm{m}, 8-63$ $\mu \mathrm{m})$, increasing again in the sand fraction that consists of inoceramid bivalve fragments and other shell fragments, foraminifera and calcispheres. There are two likely explanations: either the various groups of organisms were living under different redox conditions at different levels within the water column and bottom waters; or the grain size-related pattern of cerium anomalies is caused by varying degrees of rare earth element fractionation by different planktonic and benthic organisms such has been recognised by German and Elderfield (1990) - they observed some evidence that fractionation of rare earth element takes place between seawater and the rare earth elements incorporated into the calcite shells of foraminifera living in modern oceans. Alternative explanations related to diagenetic changes cannot be ruled out, such as (1) the effects of small amounts of diagenetic calcite within foraminifera and calcispheres; (2) selective phosphatisation at different stages of diagenesis introducing new patterns of rare earth elements or modifying old patterns. The cerium anomaly of the calcite from a bulk sample of Chalk will represent the average value from the different calcite components, each of which may represent its own degree of fractionation. However, when the total Chalk sediment is considered, the effects of this fractionation are not apparent. In our study of the lithologically variable Cenomanian-Turonian successions at three locations in England (Jeans et al. in prep.) no evidence was found of enhanced $\mathrm{Ce}^{*}$ (calcite) values in the fine-grained coccolith-rich or coarse- grained inoceramid shell-rich beds as would be expected from our detailed analysis. We draw the conclusion that any effects of differential fractionation between the organisms secreting calcitic skeletons in the Chalk Sea and its seawater have been obscured by much greater changes in the rare earth element chemistry taking place in the Sea itself.

\section{VOLCANIC ASH AND THE CERIUM ANOMALY PRESERVED IN THE ACID INSOLUBLE RESIDUES OF MARLS}

The europium anomaly is frequently used as a proxy to identify contributions of volcanic ash from evolved magmas in the Chalk of Europe (Wray 1995, 1999; Wray and Wood 1995, 1998, 2002; Wray et al. 1995, 1996; Wray and Jeans 2014). Here we use it as a measure of the volcanic contribution to marls in order to investigate its influence on the cerium anomaly. It is based upon the fact that the rare earth element europium can occur in either a di- or trivalent state. Under high temperature reducing conditions such as associated with magma evolution the divalent europium (ionic radius $1.24 \AA$ ) is readily captured and replaces $\mathrm{K}$ (ionic radius $1.33 \AA$ ) in the crystallisation of potassic feldspar, leaving the magma's rare earth element assemblage impoverished in this element and the assemblage in the feldspar crystals relatively enriched. The degree to which europium is either enriched or impoverished is referred to as the europium anomaly $\left(\mathrm{Eu}^{*}\right)-$ see Analytical Methods for calculation. The lanthanum contents are used to reflect the variation in total concentration of rare earth elements. The rare earth element analyses of the acid insoluble residues from one detrital and two volcanogenic marls are in Table 3.

Text-fig. 8 shows the relationships in the acid insoluble residue of a detrital marl from the Turonian

\begin{tabular}{|c|c|c|c|c|}
\hline Location & Horizon & Sample Numbers & Range of La (AIR)/La (calcite) values & Average values \\
\hline Dover & Louth Member & 4 & 8.1 to 13.1 & 9.8 \\
\hline & Plenus Marls & 11 & 1.8 to 6.7 & 4.2 \\
\hline & Melbourn Rock Mbr & 7 & 5.5 to 13.5 & 10 \\
\hline Melton Ross & Louth Member & 1 & - & 3.1 \\
\hline & Flixton Member & 26 & 1.8 to 9.4 & 42.8 \\
\hline Flixton & Louth Member & 1 & - & 10.5 \\
\hline & Fluxton Member & 32 & 1.2 to 22.8 & 17 \\
\hline & Melbourn Rock Mbr & 7 & 1.1 to 35.6 & 14.2 \\
\hline
\end{tabular}

Table 1. Range of La (AIR)/La (calcite) values in various stratigraphical units of the Cenomanian and Turonian Chalk at Dover, Melton Ross and Flixton 


\begin{tabular}{|c|c|c|c|c|c|c|c|c|c|c|c|c|c|c|c|}
\hline \multicolumn{16}{|c|}{ REE concentrations (ppm) in acid insoluble residues, Dover } \\
\hline Sample no. & $\mathbf{L a}$ & $\mathrm{Ce}$ & Pr & Nd & Sm & Eu & Gd & Tb & Dy & Ho & Er & $\mathbf{T m}$ & $\mathbf{Y b}$ & Lu & $\mathrm{Ce}^{*}(\mathrm{AIR})$ \\
\hline KR 90 & 47.1 & 75 & n.a. & 41 & 7.1 & 1.6 & 6.8 & 0.88 & n.a. & n.a. & n.a. & 0.34 & 3.2 & 0.43 & 0.84 \\
\hline KR 91 & 37.4 & 65 & n.a. & 33 & 5.7 & 1.4 & 4.8 & 0.84 & n.a. & n.a. & n.a. & 0.32 & 2.9 & 0.42 & 0.91 \\
\hline KR 93 & 40.9 & 68 & n.a. & 34 & 5.9 & 1.5 & 5.4 & 0.79 & n.a. & n.a. & n.a. & 0.33 & 3.0 & 0.46 & 0.88 \\
\hline KR 96 & 34.0 & 50 & n.a. & 32 & 5.4 & 1.3 & 4.9 & 0.74 & n.a. & n.a. & n.a. & 0.29 & 2.3 & 0.35 & 0.77 \\
\hline KR 101 & 34.3 & 52 & n.a. & 30 & 5.2 & 1.4 & 5.3 & 0.79 & n.a. & n.a. & n.a. & 0.28 & 2.4 & 0.34 & 0.79 \\
\hline KR 104 & 32.5 & 62 & n.a. & 28 & 5.2 & $\begin{array}{ll}1.2 \\
\end{array}$ & $\begin{array}{l}5.9 \\
\end{array}$ & $\begin{array}{ll}0.8 \\
\end{array}$ & n.a. & n.a. & n.a. & 0.29 & 3.2 & 0.42 & 1.00 \\
\hline KR 105 & $\begin{array}{lll}41.7 \\
\end{array}$ & 71 & n.a. & 36 & 7.4 & 1.6 & 7.9 & 0.94 & n.a. & n.a. & n.a. & 0.33 & 3.2 & 0.46 & 0.88 \\
\hline KR 106 & 64.5 & 87 & n.a. & 54 & 10.9 & 2.5 & 11.1 & 1.39 & n.a. & n.a. & n.a. & 0.36 & $\begin{array}{lll}4.4 \\
\end{array}$ & 0.64 & 0.71 \\
\hline KR 108 & 61.5 & 91 & n.a. & 55 & 11.5 & 2.5 & 12.1 & 1.51 & n.a. & n.a. & n.a. & 0.55 & 4.2 & 0.51 & 0.77 \\
\hline KR 109 & 59.6 & 89 & n.a. & 53 & 10.7 & 2.5 & 10.9 & 1.38 & n.a. & n.a. & n.a. & 0.54 & 4.1 & 0.53 & 0.78 \\
\hline KR 115 & 49.0 & 79 & n.a. & 43 & 8.5 & 1.9 & 7.6 & 1.02 & n.a. & n.a. & n.a. & 0.3 & 3.2 & 0.43 & 0.84 \\
\hline KR 118 & 58.9 & 82 & n.a. & 51 & 10.4 & 2.3 & 11 & 1.2 & n.a. & n.a. & n.a. & 0.57 & 3.5 & 0.5 & 0.72 \\
\hline \multicolumn{16}{|c|}{ REE concentrations (ppm) in calcite, Dover } \\
\hline Size fraction & La & $\mathrm{Ce}$ & $\operatorname{Pr}$ & Nd & Sm & Eu & Gd & Tb & Dy & Ho & Er & $\mathbf{T m}$ & $\mathbf{Y b}$ & Lu & $\mathrm{Ce}^{*}$ (calcite) \\
\hline \multicolumn{16}{|c|}{ KR119 } \\
\hline$<2 \mu \mathrm{m}$ & 9.70 & 7.2 & 1.8 & 7.5 & 1.5 & 0.35 & 1.6 & 0.23 & 1.3 & 0.25 & 0.68 & 0.09 & 0.51 & 0.07 & 0.39 \\
\hline $2-8 \mu \mathrm{m}$ & 8.12 & 5.4 & 1.3 & 5.2 & 1.0 & 0.24 & 1.1 & 0.16 & 0.97 & 0.20 & 0.58 & 0.08 & 0.50 & 0.07 & 0.36 \\
\hline $8-63 \mu \mathrm{m}$ & 9.20 & 6.1 & 1.5 & 5.9 & 1.1 & 0.27 & 1.2 & 0.19 & 1.1 & 0.24 & 0.68 & 0.10 & 0.61 & 0.09 & 0.36 \\
\hline $125-250 \mu \mathrm{m}$ & 7.40 & 4.8 & 1.2 & 4.7 & 0.9 & 0.22 & 1.0 & 0.15 & 0.92 & 0.20 & 0.56 & 0.08 & 0.49 & 0.07 & 0.36 \\
\hline $125-355 \mu \mathrm{m}$ & 7.94 & 5.2 & 1.2 & 5.0 & 1.0 & 0.23 & 1.0 & 0.16 & 0.98 & 0.22 & 0.61 & 0.09 & 0.55 & 0.08 & 0.36 \\
\hline \multicolumn{16}{|c|}{ KR145 } \\
\hline$<2 \mu \mathrm{m}$ & 10.45 & 9.9 & 2.0 & 8.5 & 1.7 & 0.38 & 1.8 & 0.25 & 1.4 & 0.28 & 0.74 & 0.10 & 0.56 & 0.08 & 0.49 \\
\hline $2-8 \mu \mathrm{m}$ & 8.42 & 7.4 & 1.4 & 57,0 & 1.1 & 0.25 & 1.2 & 0.18 & 1.0 & 0.21 & 0.61 & 0.08 & 0.51 & 0.07 & 0.48 \\
\hline $8-63 \mu \mathrm{m}$ & 9.19 & 7.8 & 1.5 & 6.0 & 1.1 & 0.26 & 1.3 & 0.19 & 1.2 & 0.25 & 0.71 & 0.10 & 0.60 & 0.09 & 0.47 \\
\hline $63-125 \mu \mathrm{m}$ & 11.40 & 11 & 2.1 & 8.7 & 1.7 & 0.37 & 1.8 & 0.27 & 1,6 & 0.32 & 0.90 & 0.12 & 0.68 & 0.10 & 0.37 \\
\hline $125-250 \mu \mathrm{m}$ & 14.24 & 14 & 2.9 & 11.9 & 2.3 & 0.50 & 2.5 & 0.36 & 2.0 & 0.41 & 1.09 & 0.14 & 0.76 & 0.11 & 0.52 \\
\hline \multicolumn{16}{|c|}{ n.a. no analysis } \\
\hline
\end{tabular}

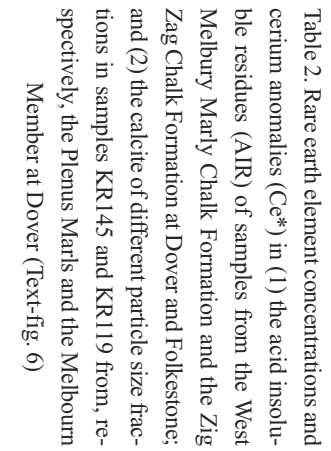




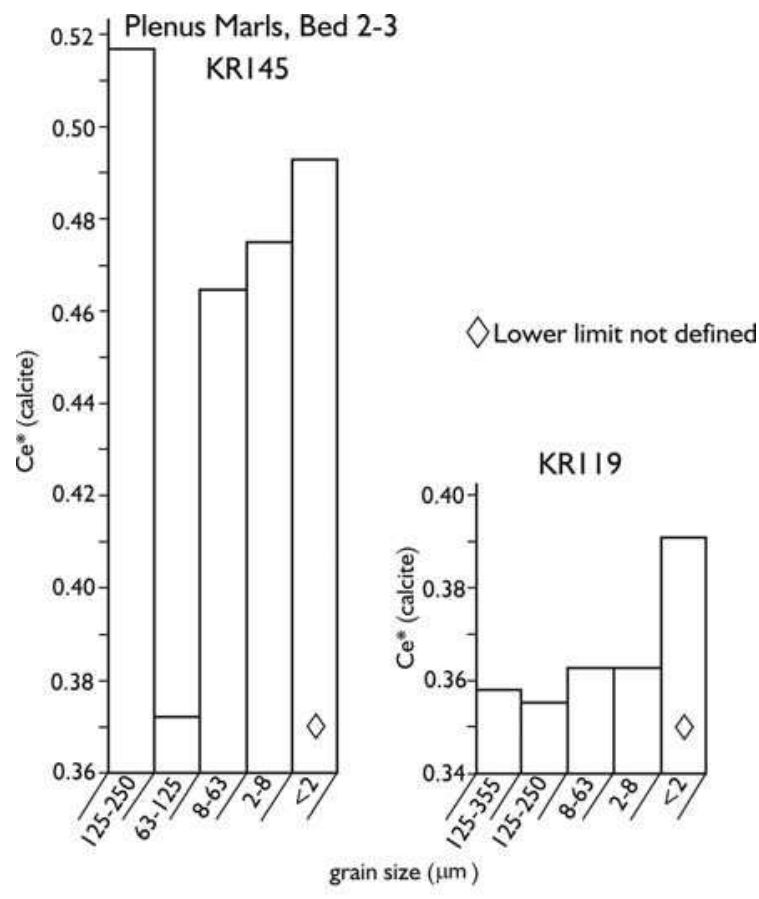

Text-fig. 7. Histograms showing the variation in the cerium anomaly (Ce*(calcite)) within the calcite of the $<2 \mu \mathrm{m}, 8-63 \mu \mathrm{m}, 125-250 \mu \mathrm{m}$ and 125-355 $\mu \mathrm{m}$ particle size fractions from samples KR145 and KR119 of the Plenus Marls and Melbourn Rock Member at Shakespeare Cliff, Dover. Text-fig. 6a for sample horizons

Chalk of Lincolnshire between grain size and (1) the content of phosphorus $\left(\mathrm{P}_{2} \mathrm{O}_{5}\right)$ and lanthanum, (2) the cerium anomaly, and (3) the europium anomaly.

The same relationships are shown for two volcanogenic marls both of Turonian age, one from the Chalk of Lincolnshire (Text-fig. 9), the other from the Chalk of Söhlde, N.W. Germany (Text-fig. 10). The detrital marl from Lincolnshire displays excellent correlation between the concentration of rare earth elements as represented by lanthanum and the phosphorus $\left(\mathrm{P}_{2} \mathrm{O}_{5}\right)$ content (Text-fig. 8a). The cerium anomalies are negative and show gradual variations, with the lowest values $(0.73,0.75)$ in the coarsest and finest particle size fractions and the highest (0.89) in the $2-8 \mu \mathrm{m}$ size fraction (Text-fig. $8 \mathrm{c}$ ). Less detailed analysis of the relationship between grain size effects in detrital marls and chalks has been made by measuring the cerium anomalies of total acid insoluble residues as well as the $<2 \mu \mathrm{m}$ fractions from a number of samples (Table 4). This demonstrates that there is no appreciable difference between the bulk acid insoluble residue and its $<2 \mu \mathrm{m}$ fraction. The acid insoluble residues from the volcanogenic marls displayed distinctly different characteristics in their rare earth element patterns. Not only are the patterns
(Text-figs 9b, 10b) of the europium anomalies distinctive, with their relatively high values associated with the sand and coarse silt fractions $(>32 \mu \mathrm{m})$ rich in feldspar and the low values in the finer silt and clay fractions $(<32 \mu \mathrm{m})$ representing argillised glass shards, whereas in the detrital marl (Text-fig. 8b) there is very little variation in values $(0.78$ to 0.86$)$. The correlation between $\mathrm{P}_{2} \mathrm{O}_{5}$ and $\mathrm{La}$ is much less obvious (Text-figs 9a, 10a) although there is still a general trend of increasing $\mathrm{P}_{2} \mathrm{O}_{5}$ with increasing La content. The poor correlation may be due to the presence of minerals of volcanogenic origin with very different rare earth element patterns from those developed in the Chalk. There is considerable variation in the $\mathrm{P}_{2} \mathrm{O}_{5}$ between the different grain size fractions (Textfigs $9 \mathrm{~d}, 10 \mathrm{~d}$ ). The cerium anomaly values (1.06 to 1.24) are positive in contrast to the negative values of the detrital marl ( 0.73 to 0.87 ): this may be related to a combination of (1) an additional supply of phosphorus from the volcanic ash; and (2) argillisation continued into the later and more anoxic stages of diagenesis.

\section{EFFECTS OF DIAGENESIS ON THE CHALK'S CERIUM ANOMALIES}

Evidence of the role that diagenesis could have played in modifying the rare earth element patterns and cerium anomalies in the Chalk is particularly relevant as it is known to have been affected by a range of diagenetic processes since its deposition that started some 90-100 Ma ago.

\section{Cerium anomalies associated with the Chalk's calcite}

Jarvis (1980, 2006) has suggested that phosphorus in organic matter reaching the Chalk seafloor was released by microbial action and under certain conditions reached sufficient concentrations to replace (phosphatise) calcium carbonate grains and skeletal matter to form apatite. Thus phosphatisation may have affected the original bioclastic skeletal grains at or just below the Chalk's seawater-sediment interface. A partially phosphatised grain would have a bottom water cerium anomaly as well as the rare earth element pattern of the original carbonate grain or skeleton. Irregular phosphatisation of carbonate grains may be the explanation of some of the variability in the phosphorus contents of the different grain size fractions of the uncemented chalk samples of Late Cenomanian age from Dover (Text-fig. 11). For two of these samples, the variation in cerium 

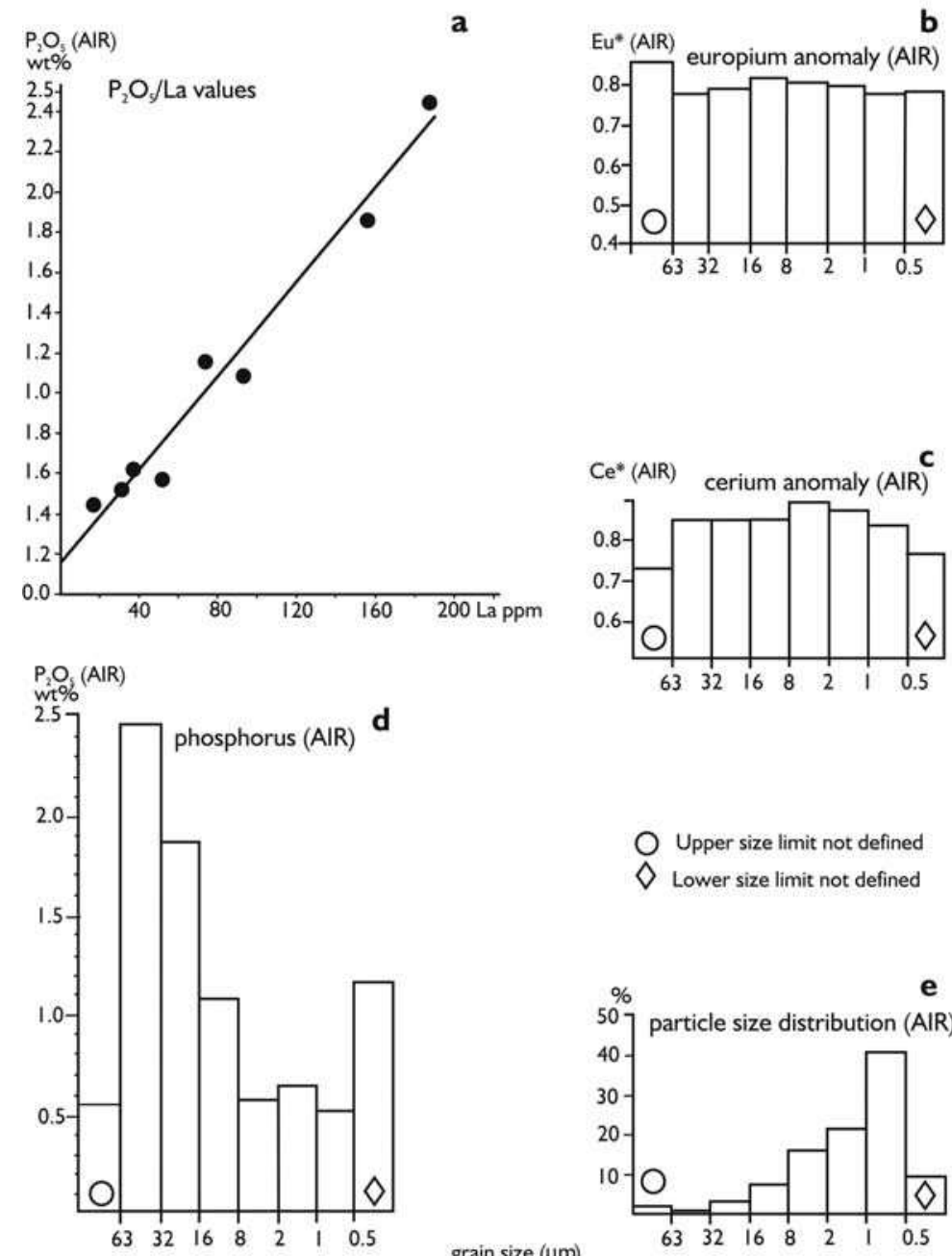

grain size $(\mu \mathrm{m})$

$\bigcirc$ Upper size limit not defined
$\diamond$ Lower size limit not defined

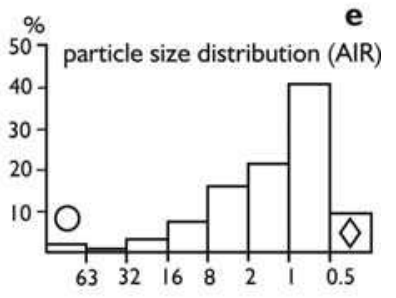

Text-fig. 8. Acid insoluble residue of sample J65 from the detrital Turonian Deepdale Upper Marl, Irby Dale, Lincolnshire (Wray and Wood 1988, fig.3). a - Crossplot of the $\mathrm{P}_{2} \mathrm{O}_{5}$ (AIR) and Ce* (AIR) for different particle size fractions. b - Eu*(AIR) values for different particle size fractions. c. Ce*(AIR) values for different particle size fractions. $\mathbf{d}$-Variations in $\mathrm{P}_{2} \mathrm{O}_{5}$ (AIR) in different particle size fractions. $\mathbf{e}$ - Particle size distribution pattern

anomaly of the calcite in relation to the grain-size fractions is shown in Text-fig. 7.

The considerable variation within each sample could be caused either by fractionation by different groups of organisms in secreting their calcite hard parts, or by variations in the cerium anomalies of the seawater in which they lived, or by later phosphatisation, or by some combination of these three processes. Present circumstantial evidence suggests that beneath the water-sediment interface the rare earth elements were not incorporated into the early and late calcite cements but mainly into the very fine-grained apatite crystals that are widespread in the $<2 \mu$ m clay mineral fractions of the Chalk (Weir and Catt 1965; Jeans 1967, 1968; Perrin 1971).

\section{Cerium anomalies associated with the Chalk's acid insoluble residues}

\section{Nodular chalks and marls}

The early diagenetic development of nodularity in the Chalk sediment by the patchy precipitation of an early Feenriched cement (Jeans 1980; Hu et al. 2014) has not altered the cerium anomaly of the acid insoluble residues in those parts of the sediment in which it occurred. Table 5 lists the cerium anomalies from the acid insoluble residues of nodules and their matrices (samples F1-10, A1-6) from 15 horizons in the Hunstanton Red Chalk Formation and the Ferriby Chalk Formation at Speeton (Jeans 1980, fig.16 for horizons). There is no systematic 

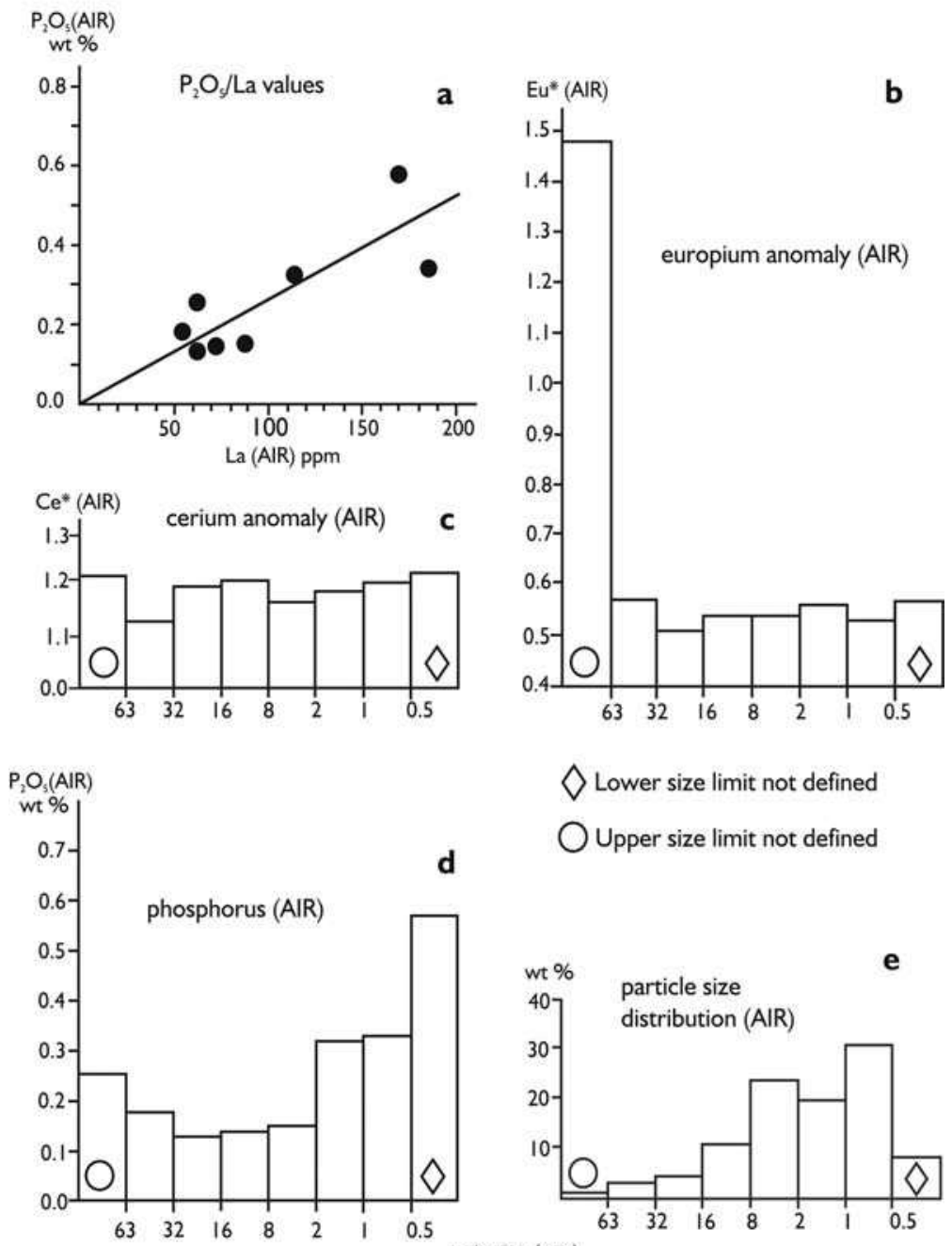

d

$\checkmark$ Lower size limit not defined

O Upper size limit not defined

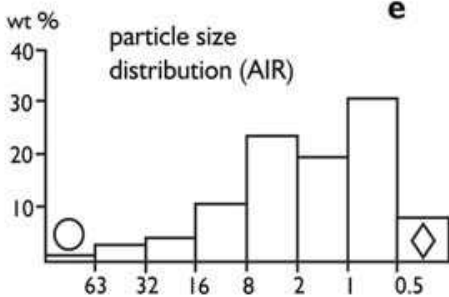

Text-fig. 9. Acid insoluble residue of sample J66 from the volcanogenic Turonian Deepdale Lower Marl, Deepdale, Lincolnshire (Wray and Wood 1988, fig.3). a - Cross-plot of $\mathrm{P}_{2} \mathrm{O}_{5}$ and $\mathrm{La}$ for different particle size fractions. $\mathbf{b}-\mathrm{Eu} *(\mathrm{AIR})$ values for different particle size fractions: the high value in the $>63 \mu \mathrm{m}$ fraction may reflect volcanogenic feldspar. $\mathbf{c}-\mathrm{Ce}$ (AIR) values for different particle size fractions. $\mathbf{d}$ - Variations in $\mathrm{P}_{2} \mathrm{O}_{5}$ (AIR) in different particle size fractions. e - Particle size distribution pattern

difference in the cerium anomaly between matrix and nodule.

\section{Alternating chalk-marl lithofacies}

This is widespread in the Cenomanian strata of southern England (e.g. Jeans 1968, fig. 4). Many authors (e.g. Gale 1990; Gale et al. 1999; Voigt et al. 2008) consider the chalk and marl beds as now preserved to represent original differences in lithology, reflecting the effects of Milankovitch cyclicity during the Late Cretaceous. There are problems with this interpretation as the alternating lithofacies can pass laterally, within tens of kilometres, into what appears to be homogeneous chalk (Jeans 1968, fig. 4). No evidence has yet been put forward to demonstrate that this cyclicity is represented by some other lithological, faunal, or geochemical feature in the homogeneous chalk. Without this evidence such apparent cyclicity could have resulted from a diagenetic unmixing of a homogeneous impure chalk such as has been suggested by Ricken (1987). More recently the general problem of assessing the origin and significance of rhythmic carbonate successions has been reviewed by Westphal and Munnecke (2003) and Westphal et al. (2010). Where such alternations are well developed in the Chalk, as in the Zigzag Chalk Formation of mid to late Cenomanian age at Ballard Cliff (Text-fig. 12), 
REDOX CONDITIONS IN THE LATE CRETACEOUS CHALK SEA

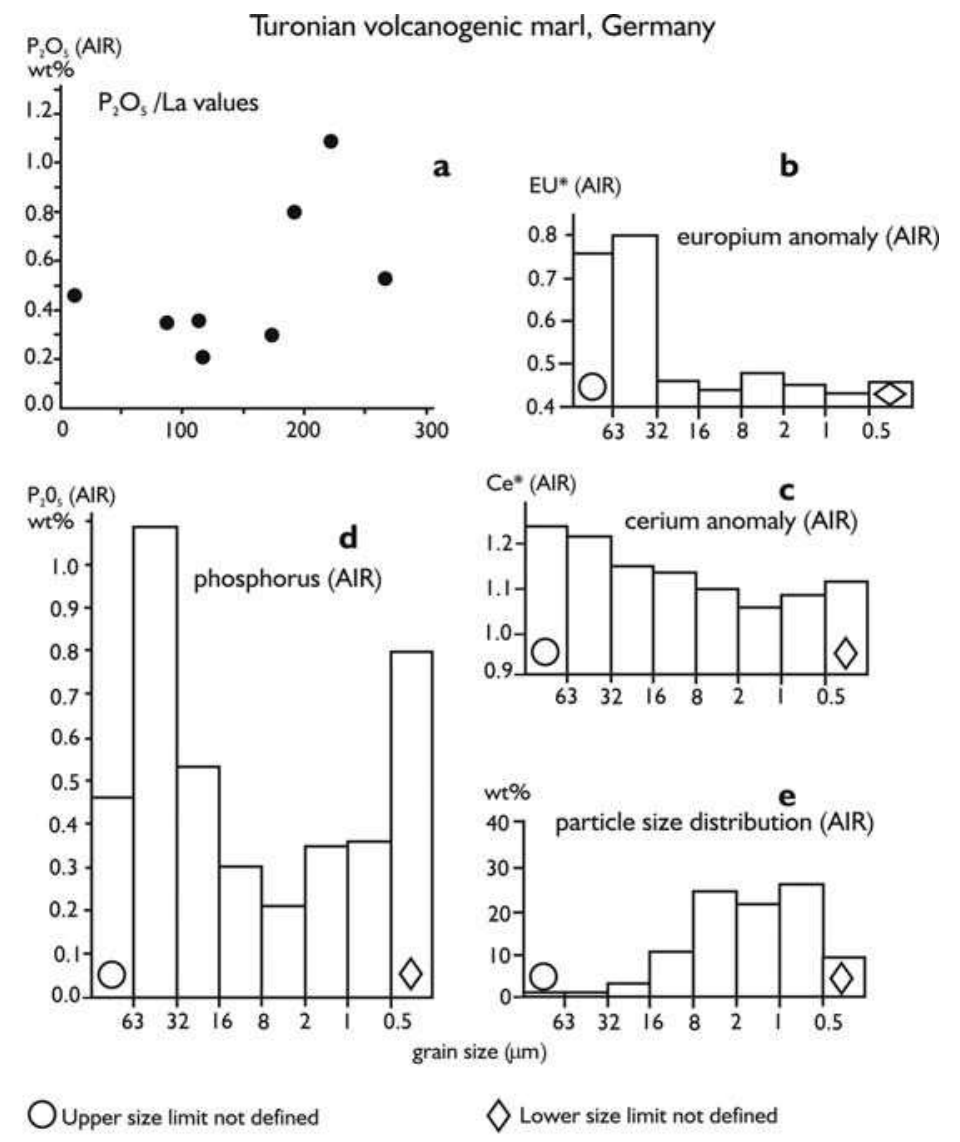

Text-fig. 10. Acid insoluble residue of sample Ge21 from the Turonian volcanogenic marl (Tuff D), Söhlde, N.W. Germany. a - Cross-plot of $\mathrm{P}_{2} \mathrm{O}_{5}$ and La for different particle size fractions. $\mathbf{b}-\mathrm{Eu}^{*}(\mathrm{AIR})$ values for different particle size fractions; the high values in the $>32 \mu \mathrm{m}$ fraction reflect abundant volcanogenic feldspar. $\mathbf{c}-\mathrm{Ce}$ (AIR) values for different particle size fractions. $\mathbf{d}$ - Variations in $\mathrm{P}_{2} \mathrm{O}_{5}$ in different particle size fractions. e - Particle size distribution pattern

there is considerable trace element and stable isotope evidence that diagenetic processes have played an important role in the differentiation of the chalk and marl units (Jeans et al. 2012, text-fig. 10). Text-fig. 12 shows the relationships between the cerium anomaly of the acetic acid insoluble residue and trace elements (Fe, Mn) of the bulk calcite in this succession of chalk and marl units. The rare earth element data is in Table 3. Typically the marl units have acid insoluble residues with enhanced cerium anomalies and a bulk calcite with lower Fe and Mn content than the chalk units. The enhanced cerium anomalies suggest that the marl units experienced a more anoxic environment in their diagenesis than the chalk units. Other sequences of alternating chalk-marl lithofacies - such as those that make up the Late Cenomanian-Early Turonian Melbourn Rock Member at Eastbourne, Sussex (Jeans et al. 2012, text-fig. 11) - are known to display geochemical patterns different from those at Ballard Cliff but which are still related to diagenesis.
Late diagenetic calcite cementation is responsible for regional variations in the Chalk's lithification (Jeans et al. 2014). It has been investigated in the Louth Member at Dover (unlithified) and at three locations in eastern England (Elsham, Tetford, South Thoresby) where it is lithified. Table 6 shows that there is no variation in the cerium anomaly of the acid insoluble residues corresponding to that in the bulk specific gravity (1.65-2.17), porosity (20-39 vol. \%) and calcite cement (0-20 vol. \%).

Late diagenetic sulphidisation Cross-cutting the Cenomanian and Albian strata in eastern England are sulphidisation zones in which various strata of pink and red chalk and marl have been discoloured with the development of iron sulphides (Text-fig. 13). This is related to a late diagenetic event, some 15 or more million years after the deposition of these strata, linked to tectonic activity along the Flamborough Fault Zone which may be late Cretaceous to early Palaeocene in 


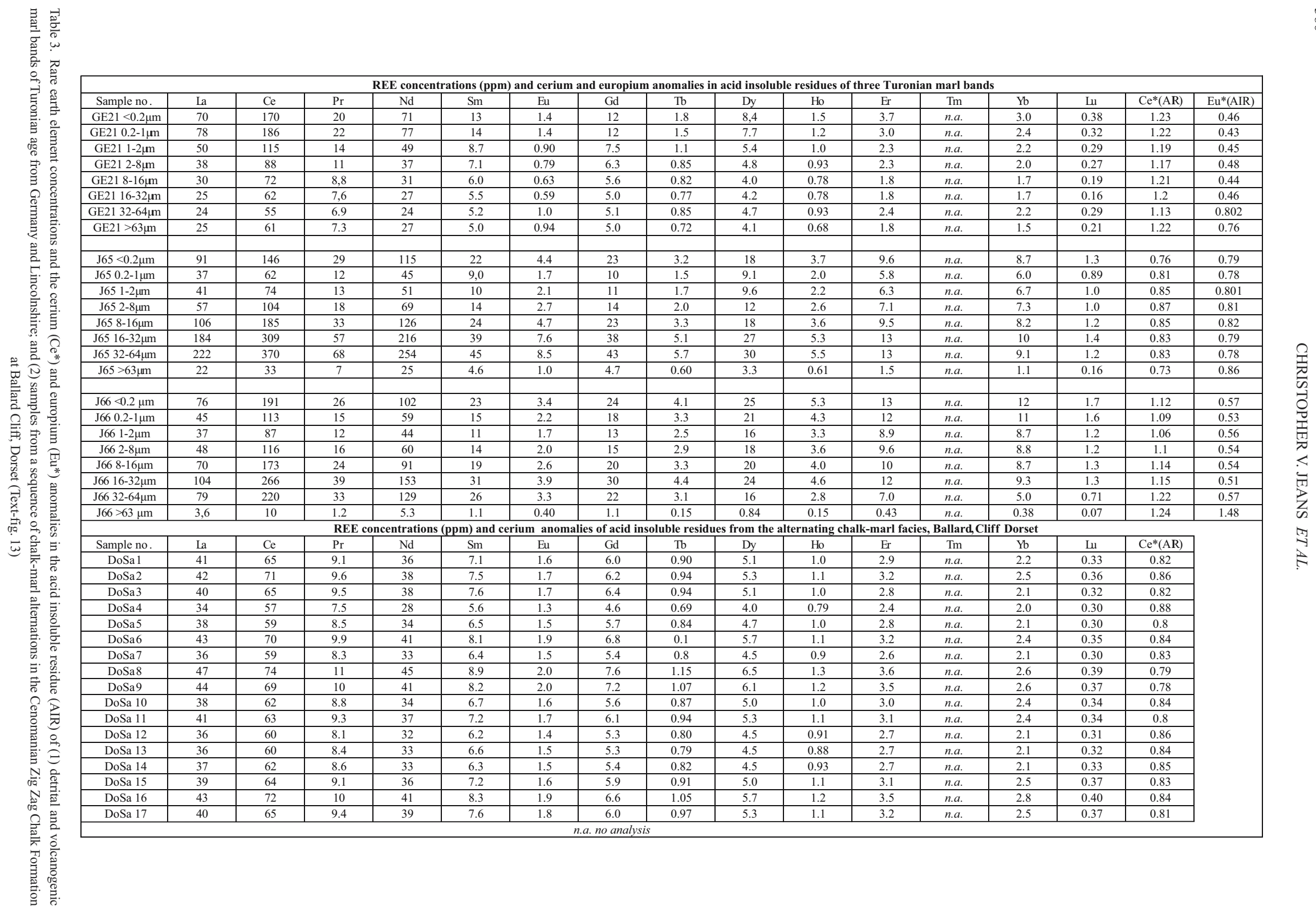



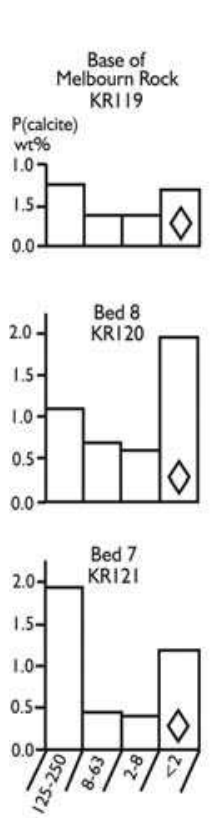
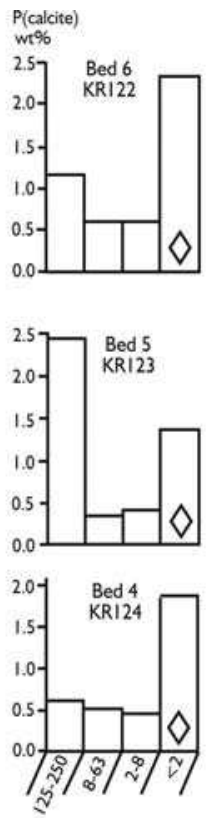
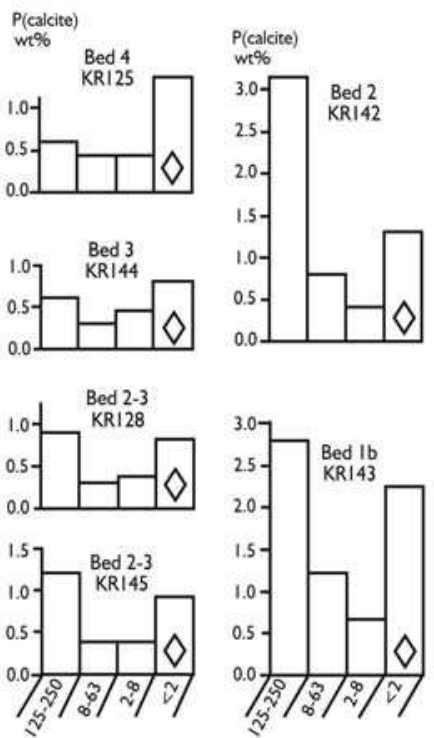

rain size $(\mu \mathrm{m})$

$\checkmark$ Lower size limit not defined
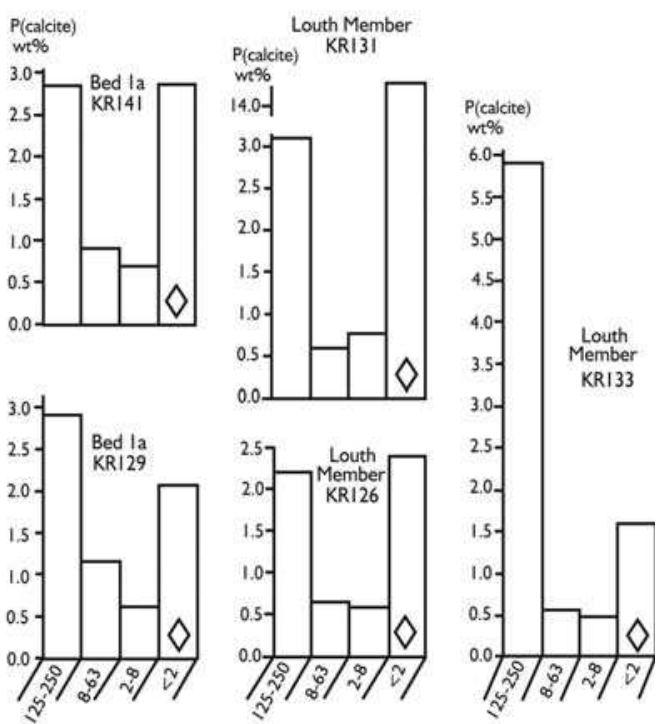

Text-fig. 11. Histograms showing the variation in phosphorus (P) within the bulk calcite of the $<2 \mu \mathrm{m}, 2-8 \mu \mathrm{m}, 8-63 \mu \mathrm{m}$ and $125-250 \mu \mathrm{m}$ particle size fractions from various samples of the Plenus Marls and adjacent sediments at Shakespeare Cliff, Dover (Text-fig. 6a for sample horizons). KR131 is the only sample with a $<2 \mu \mathrm{m}$ fraction which has a phosphorus content (14 wt \%) in excess of the maximum value $(\sim 2.5 \mathrm{wt} \%)$ recorded by Siesser (1977) for the skeletal calcite of recent and Tertiary Coccolithophoridae

age (Starmer 1995, 2008, 2013: Jeans et al. 2014). This allowed solutions rich in sulphate $\left(\right.$ or $\mathrm{H}_{2} \mathrm{~S}$ ) and hydrocarbons to invade these strata along faults and joints causing widespread anoxia and sulphidisation of the precursor of the hematite colouring pigment. Table 6 shows that the cerium anomalies of the acid insoluble residues at Elsham from within the sulphidisation zone of the Louth Member average 0.57 whereas out- side the zone at Tetford and South Thoresby the values average 0.56 . There is thus no appreciable difference in the cerium anomalies of the acid insoluble residues from within and outside the sulphidisation zone albeit the number of analyses is small. The sulphidisation is likely to have occurred under anoxic conditions, when the pore waters would have had a positive or neutral cerium anomaly. The most likely explanation is that

\begin{tabular}{|c|c|c|c|}
\hline Sample & Location/horizon & \multicolumn{2}{|c|}{ Ce*(AIR) } \\
\hline & & Tota 1 & $<2 \mu \mathrm{m}$ \\
\hline LR320 & Flixton, Welton Formation & 1.17 & 1.11 \\
\hline LR312 & Flixton,Melbourn Rock, Welton Formation & 0.82 & 0.85 \\
\hline LR309 & Flixton, Flixton Member, Welton Formation & 0.54 & 0.83 \\
\hline LR302 & Flixton, Variegated Beds, Welton Formation & 1.18 & 1.11 \\
\hline Ysa85 & Flixton, Variegated Beds, Welton Formation & 1.1 & 1.2 \\
\hline ++(56, 57) & Speeton, 2.96m below base of Nettleton & & \\
& Member,Ferriby Fm & 0.81 & 0.85 \\
\hline LR368 & Tetford Hill, Flixton Member, Ferriby Fm & 0.57 & 0.59 \\
\hline LR382 & Welton, Louth Member, Ferriby Fm & 0.51 & 0.51 \\
\hline KR141 & Dover, Bed 1a, Plenus Marls & 0.93 & 0.93 \\
\hline
\end{tabular}

Table 4. Ce (AIR) anomalies of the total AIR and the $<2 \mu \mathrm{m}$ AIR fraction of chalks from eastern and southern England 


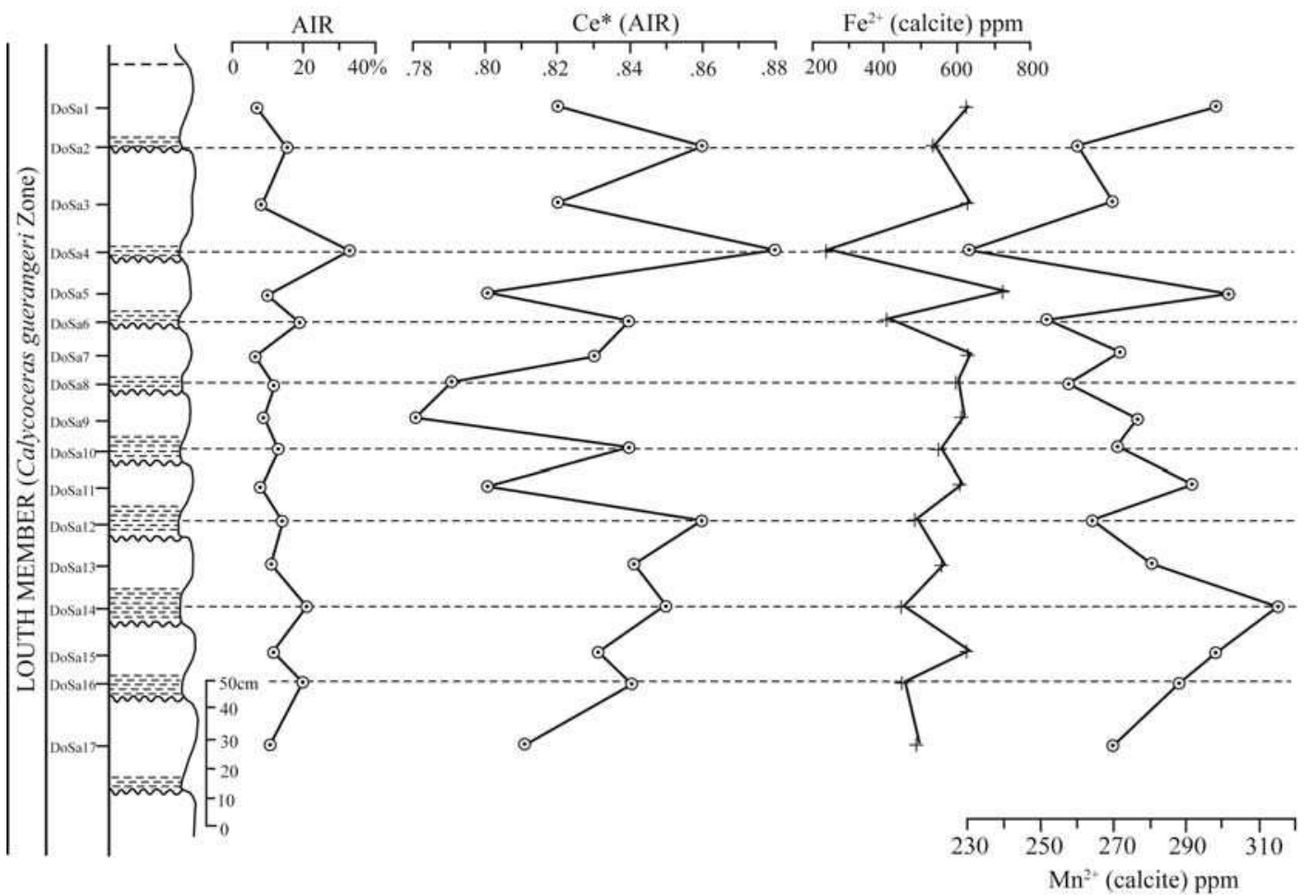

Text-fig. 12. Sequence of chalk-marl alternations in the Louth Member (Zig Zag Formation, Ballard Cliff, Dorset) showing the generally similar variations of the acid insoluble residue (AIR) and its cerium anomaly ( $\mathrm{Ce}(\mathrm{AIR}))$ in contrast to the pattern of $\mathrm{Fe}^{2+}\left(\right.$ calcite) and $\mathrm{Mn}^{2+}($ calcite) variation in the bulk calcite

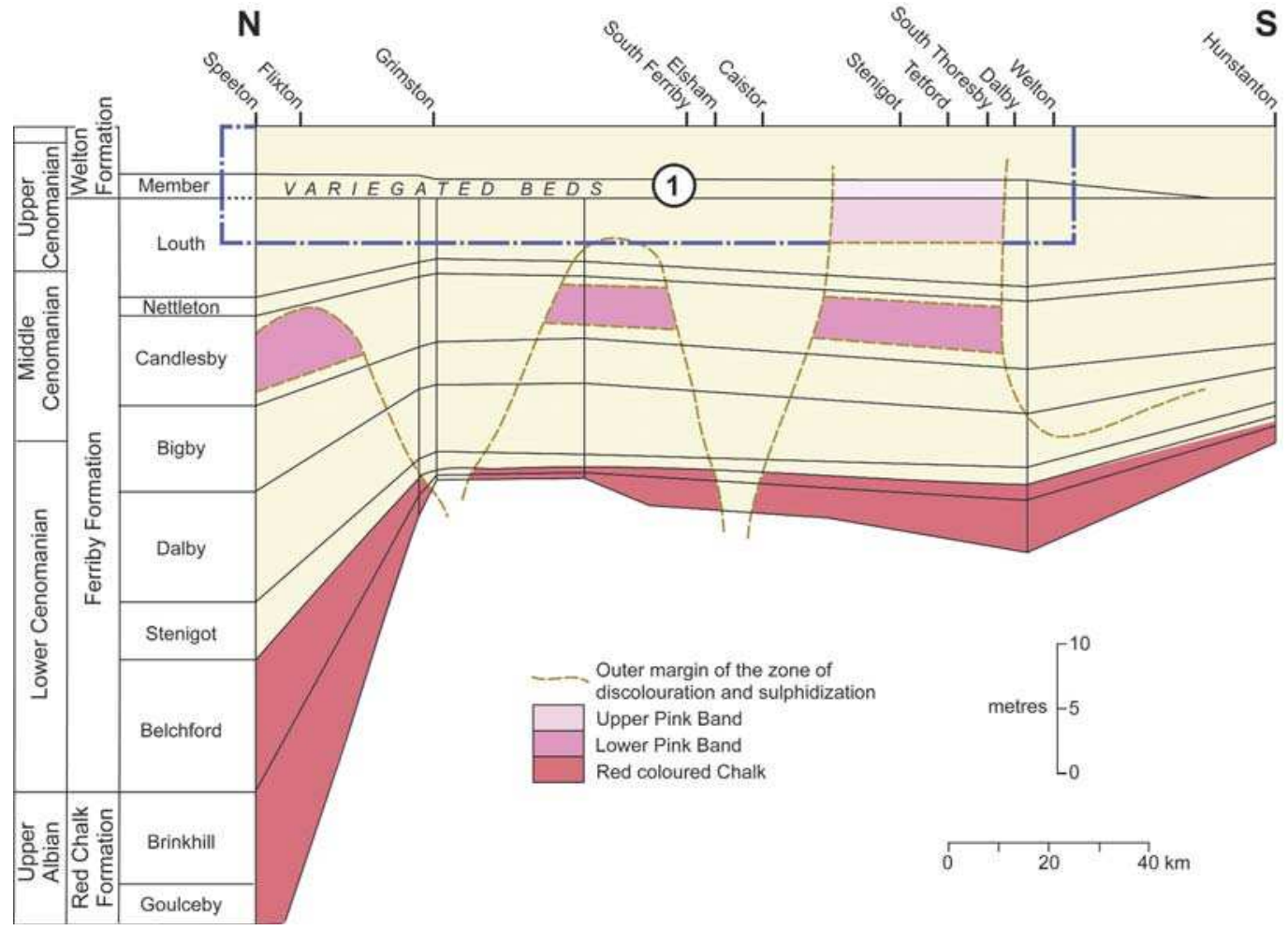

Text-fig. 13. Horizontal section through the Red Chalk, Ferriby and basal Welton formations in eastern England based on Bower and Farmery (1910), Wood and Smith 1978) and Jeans (1980). The extent of the main bands of red and pink chalk and the zone of discolouration are shown. Zone 1 indicates the stratigraphical and regional extent of a detailed geochemical investigation undertaken on the cementation of the Chalk by Jeans et al. (2014). The cross-cutting zones of discolouration are caused by sulphidisation as the result of allochthonous solutions rich in sulphate (or $\mathrm{H}_{2} \mathrm{~S}$ ) and hydrocarbons penetrating the Chalk along active tectonic zones perhaps some $15 \mathrm{Ma}$ or more years after their deposition 


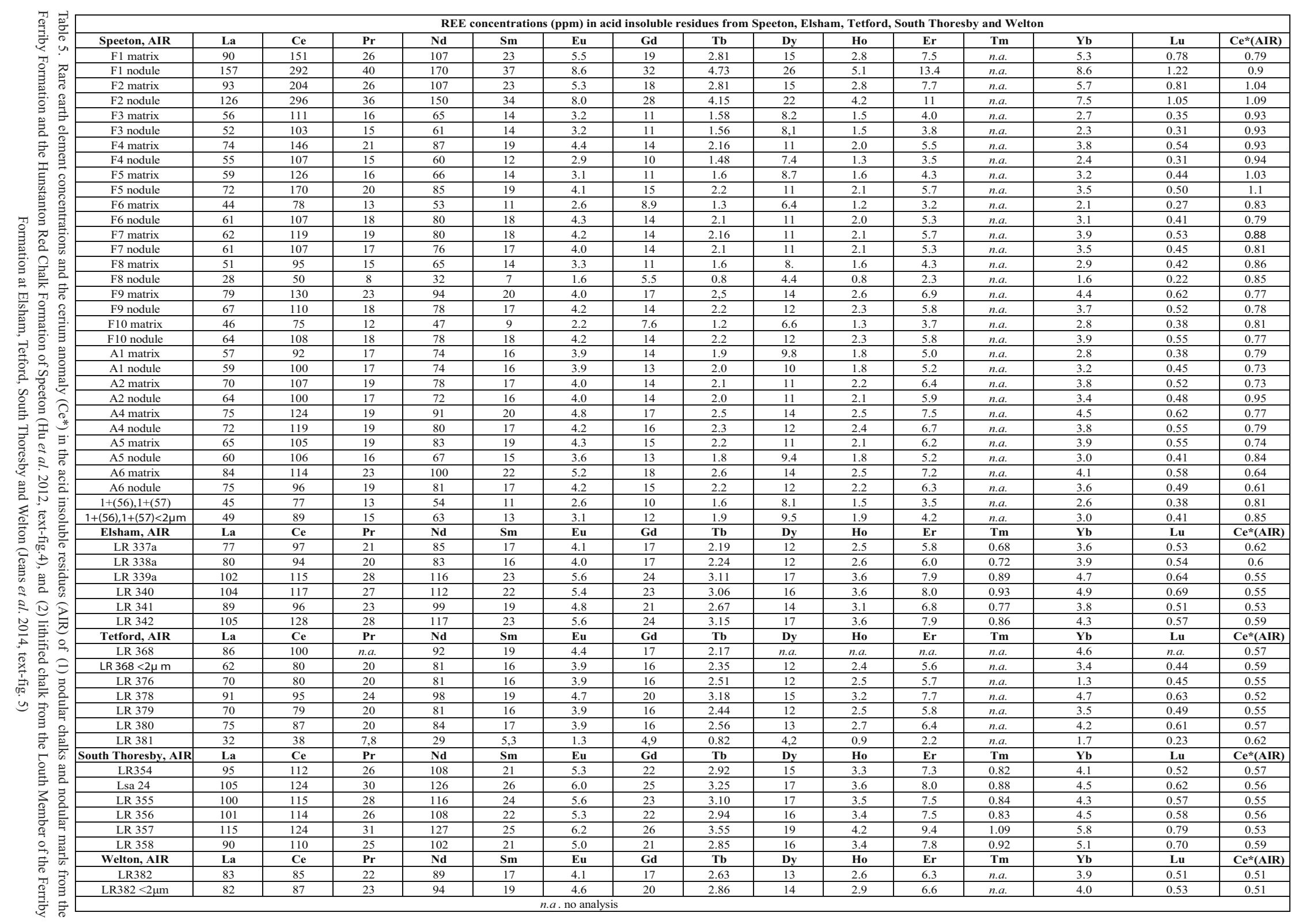




\begin{tabular}{|c|c|c|c|c|c|c|c|}
\hline \multicolumn{2}{|c|}{$\begin{array}{c}\text { Sulphidised red facies. } \\
\text { Elsham }\end{array}$} & \multicolumn{2}{c|}{$\begin{array}{c}\text { Red facies. } \\
\text { Tetford Hill }\end{array}$} & \multicolumn{2}{c|}{$\begin{array}{c}\text { Red facies. } \\
\text { South Thoresby }\end{array}$} & \multicolumn{2}{c|}{$\begin{array}{c}\text { Non-red facies. } \\
\text { Dover }\end{array}$} \\
\hline Sample & Ce*(AIR) & Sample & Ce*(AIR) & Sample & Ce*(AIR) & Sample & Ce*(AIR) \\
\hline LR 342 & 0.59 & LR 376 & 0.55 & LR 354 & 0.57 & KR129 & 0.62 \\
LR 341 & 0.53 & LR 378 & 0.52 & Ls a 24 & 0.56 & KR131 & 0.51 \\
LR 340 & 0.55 & LR 379 & 0.55 & LR 355 & 0.55 & KR126 & 0.53 \\
LR 339a & 0.55 & LR 380 & 0.57 & LR 356 & 0.56 & KR132 & 0.62 \\
LR 338a & 0.6 & LR 381 & 0.62 & LR 357 & 0.53 & KR118 & 0.6 \\
LR 337a & 0.62 & & & LR 358 & 0.59 & & \\
\hline Average Ce*(AIR) & $\underline{0.57}$ & & $\underline{0.56}$ & & $\underline{0.56}$ & & $\underline{0.58}$ \\
\hline Av. bulk specific gravity & 2.12 & & 2.12 & & 2.17 & & 1.65 \\
\hline Av. porosity & $21.5 \%$ & & $21.5 \%$ & & $19.6 \%$ & & $39.3 \%$ \\
\hline Estimated volume of & $17.8 \%$ & & $17.8 \%$ & & $19.6 \%$ & & $0.0 \%$ \\
Fe-rich cement & & & & & & & \\
\hline
\end{tabular}

Table 6. Ce (AIR) anomalies, bulk specific gravity, porosity and cement volume in three diagenetic facies of the Louth Member, eastern and southern England.. The sulphidised red facies of Elsham represent chalk that originally contained red hematite pigment that has been lost during late-stage non-intrinsic diagenesis as the result of invasive pore fluids rich in sulphate ( $\mathrm{H}_{2} \mathrm{~S}$ ) and hydrocarbons (see Text-fig. 9 and Jeans et al. 2014). The red facies at Tetford Hill and South Thoresby are examples of the Upper Pink Band where it is preserved. The non-red facies of the Louth Member at Dover has never contained a hematite pigment during its diagenetic history

carbonate-fluorapatite, the preferred host to the rare earth elements, was either no longer being precipitated or, if it was, it was in such minor amounts that its content of rare earth elements did not modify the overall pattern of the acid insoluble residue.

\section{CONCLUSIONS}

Our investigation of the cerium anomalies in the Upper Cretaceous Chalk of England suggests the following:

1. Two population of rare earth elements are preserved, one in the calcite fraction, the other in the carbonate-fluorapatite of the acetic acid insoluble residue.

2 . The two rare earth element populations can be differentiated analytically by either selective acid dissolution using cold 1 molar acetic acid or by timed selective acid dissolution using cold $2 \%$ nitric acid.

3. The cerium anomaly associated with the pattern of rare earth elements in the Chalk's calcite is an indicator of the general palaeoredox conditions in the Chalk Sea although there is evidence that there may have been some fractionation in the formation of the calcite shells of the fossil organisms that make up the Chalk.

4. The cerium anomaly linked to the pattern of rare earth elements associated with the carbonate-fluorapatite of the acetic acid insoluble residue is a measure of the average palaeoredox conditions in the porewaters of the Chalk sediment during the phase of diagenesis when the host apatite mineral was being precipitated. Later stages of diagenesis are not recorded.

5. Diagenesis has had no apparent effect on the cerium anomalies of either the calcite fraction or the acetic acid insoluble residue.

6. Contributions of volcanic ash may modify the cerium anomaly of the acetic acid insoluble residue by the addition of phosphorus, thus allowing the precipitation of carbonate-fluorapatite to extend into conditions of greater anoxia.

A later paper (Jeans et al. in preparation) will demonstrate how the application of the cerium anomaly method in combination with other geochemical proxies to three sections (Flixton, Melton Ross, Dover) in the Chalk of England spanning the CenomanianTuronian Anoxic Event provides a new insight into the oceanographic conditions linked to this ocean-wide event and its associated faunal changes.

\section{Acknowledgements}

We wish to thank the following: Paul Henderson for originally introducing the problem of the positive anomalies of the Chalk; Harry Elderfield for help with literature on rare earth elements and critical discussion; Ian Jarvis, Malcolm Hart, Rory Mortimore and Christopher Wood for constructive comments on an earlier manuscript; Sandra Last and Alison Harvey for patiently and skilfully interpreting handwritten manuscripts; Philip Stickler, Sharon Capon and Xiu-fang Hu for drafting the figures. 


\section{REFERENCES}

Blumenberg, M. and Wiese, F. 2012. Imbalanced nutrients as triggers for black shale formation in a shallow shelf setting during the OAE 2 (Wunstorf, Germany). Biogeosciences, 9, 4139-4153.

Bower, C.R. and Farmery, J.T. 1910. The zones of the Lower Chalk of Lincolnshire. Proceedings of the Geologists' Association, 11, 333-359.

de Baar, H.J.W., German, C.R., Elderfield, H. and van Gaas, P. 1988. Rare earth element distributions in anoxic waters of the Cariaco Trench. Geochimica et Cosmochemica Acta, 52, 1203-1219.

Gale, A.S. 1990 A Milankovitch scale for Cenomanian time. Terra Nova, 1, 420-425.

Gale, A.S., Young, J.R., Shackleton, N.J., Crowhurst, S.J. and Wray, D.S. 1999. Orbital tuning of Cenomanian marly chalk successions: towards a Milankovitch timescale for the Late Cretaceous. Philosophical Transactions of the Royal Society, London. Series A, 357, 1815-1829.

German, C.R. and Elderfield, H. 1989. Rare earth elements in Saanich Inlet, British Columbia, a seasonally anoxic basin. Geochimica Cosmochimica Acta, 53, 2561-2571.

German, C.R. and Elderfield, H. 1990. Application of the Ce anomaly as a paleoredox indicator: the ground rules. $\mathrm{Pa}$ leoceanography, 5, 823-833.

Hönisch, B., Allen, K.A., Lea, D.W., Spero, H.J., Eggins, S.M., Arbuszewski, J., de Menocal, P., Rosenthal, Y., Russell, A.D. and Elderfield, H. 2013. The influence of salinity on $\mathrm{Mg} / \mathrm{Ca}$ in planktic foraminifera - Evidence from cultures, core-top sediments and complimentary $\delta^{18}$ O. Geochemica et Cosmochemica Acta, 121, 196-213.

Henderson, P. and Williams, C.T. 1981. Application of intrinsic Ge detectors to the instrumental neutron activation analysis for rare earth elements in rocks and minerals. Journal of Radioanalytical Chemistry, 67, 445-452.

Hu, X.F., Jeans, C.V. and Dickson, J.A.D. 2012. Geochemical and stable isotope patterns of calcite cementation in the Upper Cretaceous Chalk, UK: Direct evidence from calcite-filled vugs in brachiopods. Acta Geologica Polonica, 62, 143-172.

Hu, X.F., Long, D. and Jeans, C.V. 2014. A novel approach to the study of the development of the Chalk's smectite assemblage. Clay Minerals, 49, 277-297.

Jarvis, I. 1980. Geochemistry of phosphatic chalks and hardgrounds from the Santonian to early Campanian (Cretaceous) of northern France. Journal of the Geological Society, London, 137, 705-721.

Jarvis, I. 1984. Rare earth element geochemistry of late Cretaceous Chalks and phosphorites from northern France. Special Publication of the. Geological Survey of India, 17, 179-190.

Jarvis, I. 2006. The Santonian-Campanian phosphatic chalks of England and France. Proceedings of the Geologists 'Association, 117, 219-237

Jeans, C.V. 1967. The Cenomanian Rocks of England. Unpublished $\mathrm{PhD}$ thesis, University of Cambridge, $156 \mathrm{pp}$.

Jeans, C.V. 1968. The origin of the montmorillonite of the $\mathrm{Eu}-$ ropean Chalk with special reference to the Lower Chalk of England. Clay Minerals, 7, 311-329.

Jeans, C.V. 1980. Early submarine lithification in the Red Chalk and Lower Chalk of eastern England; a bacterial control model and its implications. Proceedings of the Yorkshire Geological Society, 43, 81-157.

Jeans, C.V., Hu, X.F. and Mortimore, R.N. 2013. Calcite cements and the stratigraphical significance of the marine $\delta^{13} \mathrm{C}$ carbonate reference curve for the Upper Cretaceous Chalk of England. Acta Geologica Polonica, 62, 173-196.

Jeans, C.V., Long, D., Hu, X.F. and Mortimore, R.N. 2014. Regional hardening of Upper Cretaceous Chalk in eastern England, UK: trace element and stable isotope patterns in the Upper Cenomanian and Turonian Chalk and their significance. Acta Geologica Polonica, 64, 419-455.

Jeans, C.V., Tosca, N.J., Boreham, S. and Hu, X.F. 2014. Clay mineral-grain size-calcite cement relationships in Upper Cretaceous Chalk, UK: a preliminary investigation. Clay Minerals, 49, 299-325.

Mortyn, P.G., Elderfield, H. Anand, P. and Greaves, M.J. 2005. An evaluation of controls on planktonic foraminiferal $\mathrm{Sr} / \mathrm{Ca}$ : comparison of water column and core top data from a North Atlantic transect. G3, Geochemistry. Geophysics Geosystems, 6. DOI 10.1029/2005GC001047

Perrin, R.M.S. 1964. The analysis of chalk and other limestones for geochemical studies, pp. 207-221. In: Analysis of Calcareous Materials. Monograph of the Society of Chemical Industries (London), 18, 481 pp.

Ricken, W. 1986. Diagenetic bedding: a model for limestonemarl alternations. Berlin, Springer, $210 \mathrm{pp}$.

Sadekov, A.Y., Bush, F., Kerr, J. Ganeshram, R. and Elderfield, H. 2014. Mg/Ca composition of benthic foraminifera Miliolacea as a new tool of paleoceanography. Paleoceanography, 29, 2014PA002654. ISSN 1944-9186 DOI 10.1002/2014PA002654.

Siesser, W.G. 1977. Chemical composition of calcareous nannofossils. South African Journal of Science, 73, 283-285.

Starmer, I.C. 1995. Deformation of the Upper Cretaceous Chalk at Selwicks Bay, Flamborough Head, Yorkshire: its significance in the structural evolution of north-east England and the North Sea Basin. Proceedings of the Yorkshire Geological Society, 50, 213-228.

Starmer, I.C. 2008. The concentration of folding and faulting in the Chalk at Staple Newk (Scale Nab) near Flamborough, East Yorkshire. Proceedings of the Yorkshire Geological Society, 57, 95-106.

Starmer, I.C. 2013. Folding and faulting in the Chalk at Dykes End, Bridlington Bay, East Yorkshire, resulting from re- 
activations of the Flamborough Head Fault Zone. Proceedings of the Yorkshire Geological Society, 59, 195-201.

Voigt, S. Wilmsen, M., Mortimore, R.N. and Voigt, T. 2003. Cenomanian palaeotemperatures derived from the oxygen isotopic composition of brachiopods and belemnites: evaluation of Cretaceous palaeotemperature proxies. International Journal of Earth Sciences (Geologische Rundschau), 92, 285-299.

Voigt, S., Erbacher, J., Mutterlose, J., Weiss, W., Westerhold, T., Wiese, F., Wilmsen, M. and Wonik, T. 2008. The Cenomanian - Turonian of the Wunstorf Section (North Germany): global stratigraphic reference section and new orbital time scale of Oceanic Anoxic Event 2. Newsletters on Stratigraphy, 43, 65-89.

Weir, A.H. and Catt, J.A. 1965. The mineralogy of some Upper Chalk samples from the Arundel area, Sussex. Clay Minerals, 6, 97-110.

Westphal. H. and Munnecke, A. 2003. Limestone-marl alternations: a warm water phenomena. Geology, 31, 263-266.

Westphal, H, Hilgen, F. and Munnecke, A. 2010. An assessment of the suitability of individual rhythmic carbonate successions for astrochronological application. EarthScience Reviews, 99, 19-30.

Wood, C.J. and Smith, E.G. 1978. Lithostratigraphical classification of the Chalk in North Yorkshire, Humberside and Lincolnshire. Proceedings of the Yorkshire Geological Society, 42, 263-287.

Wray, D.S. 1999. Identification and long-range correlation of bentonites in Turonian - Coniacian (Upper Cretaceous) chalks of northwest Europe. Geological Magazine, 136, 361-371.

Manuscript submitted: $15^{\text {th }}$ September 2014

Revised version accepted: $15^{\text {th }}$ July 2015
Wray, D.S. and Jeans, C.V. 2014. Chemostratigraphy and provenance of clays and other noncarbonated minerals in chalks of Campanian age (Upper Cretaceous) from Sussex, southern England. Clay Minerals, 49, 327-340.

Wray, D.S. and Wood, C.J. 1995. Geochemical identification and correlation of tuff layers in Lower Saxony, Germany. Berliner Geowissenschaftliche Abhandlungen, E16.1, 215-226.

Wray, D.S. and Wood, C.J. 1998. Distinction between detrital and volcanogenic clay-rich beds in Turonian-Coniacian chalks of eastern England. Proceedings of the Yorkshire Geological Society, 52, 95-105.

Wray, D.S. and Wood, C.J. 2002. Identification of a new bentonite in sediments of Mid-Turonian age from Lower Saxony, Germany and its correlation within NW Europe. Austrian Academy of Science Series: Schriftenreihe der Erdwissenschaftlichen Kommissionen, 15, 47-58.

Wray, D.S., Kaplan, U. and Wood, C.J. 1995. Tuff-Vorkommen und ihre Bio- und Eventstratigraphie im Turon des Teutoburger Waldes, der Egge und des Haarstrangs. Geologie und Paläontologie in Westfalen, 37, 1-53.

Wray, D.S., Wood, C.J., Ernst, G. and Kaplan, U. 1996. Geochemical subdivision and correlation of clay-rich beds in Turonian sediments of northern Germany. Terra Nova, $\mathbf{8}$, 603-610.

Yu, J., Elderfield, H. and Hönisch, B. 2007. B/Ca in planktonic foraminifera as a proxy for surface seawater $\mathrm{pH}$. Paleoceanography, 22, PA2202. DOI 10.1029/2006PA001347

Yu, J., Elderfield, H., Jin, Z. and Booth, L. 2008. A strong temperature effect on $\mathrm{U} / \mathrm{Ca}$ in planktonic foraminiferal carbonates. Geochemica et Cosmochemica Acta , 72, 49885000. ISSN 0016-7037 DOI 10.1016/j.gca.2008.07.011 